\title{
Sepsis in head and neck cancer patients treated with chemotherapy and radiation: Literature review and consensus
}

\author{
Aurora Mirabile $^{\mathrm{a}}$, Gianmauro Numico ${ }^{\mathrm{b}}$, Elvio G. Russi ${ }^{\mathrm{c}, *}$, Paolo Bossi ${ }^{\mathrm{a}}$, Fulvio Crippa ${ }^{\mathrm{d}}$, \\ Almalina Bacigalupo ${ }^{\mathrm{e}}$, Vitaliana De Sanctis ${ }^{\mathrm{f}}$, Stefania Musso ${ }^{\mathrm{g}}$, Anna Merlotti ${ }^{\mathrm{h}}$, \\ Maria Grazia Ghi ${ }^{i}$, Marco C. Merlano ${ }^{j}$, Lisa Licitra ${ }^{a}$, Francesco Moretto ${ }^{k}$, Nerina Denaro $^{\mathrm{j}}$, \\ Orietta Caspiani $^{1}$, Michela Buglione ${ }^{\mathrm{m}}$, Stefano Pergolizzi ${ }^{\mathrm{n}}$, Antonio Cascio ${ }^{\mathrm{o}}$, Jacques Bernier $^{\mathrm{p}}$, \\ Judith Raber-Durlacher $^{\mathrm{q}}$, Jan B. Vermorken ${ }^{\mathrm{r}}$, Barbara Murphy ${ }^{\mathrm{s}}$, Marco V. Ranieri ${ }^{\mathrm{t}}$, \\ R. Phillip Dellinger ${ }^{\mathrm{u}}$ \\ ${ }^{\text {a }}$ Head and Neck Medical Oncology Unit, Fondazione IRCCS Istituto Nazionale Tumori, Milan, Italy \\ ${ }^{\mathrm{b}}$ Medical Oncology Unit, Ospedale U. Parini, Viale Ginevra 3, 11100 Aosta, Italy \\ ${ }^{\mathrm{c}}$ Radiation Oncology Department, AO. S. Croce e Carle, Cuneo, Italy \\ ${ }^{\mathrm{d}}$ Infectious Disease Department, AO.S. Paolo, Milano, Italy \\ ${ }^{e}$ Radio-Oncology Department, IRCCS San Martino - IST, Largo R Benzi 10, 16132 Genoa, Italy \\ ${ }^{\mathrm{f}}$ Department of Radiotherapy, University "La Sapienza" Rome Italy \\ ${ }^{g}$ Critical Care Department, AO S. Croce e Carle Cuneo, Italy \\ ${ }^{\mathrm{h}}$ Radiation Oncology Department, Ospedale di Circolo di Busto Arsizio, Italy \\ ${ }^{i}$ Department of Oncology, Ospedale dell Angelo, Via Paccagnella 11, 30174 Mestre-Venezia, Italy \\ j Medical Oncology Department, AO. S. Croce e Carle, Cuneo, Italy \\ ${ }^{k}$ Radiotherapy Department, AOU Città della Salute e della Scienza, Turin, Italy \\ ${ }^{1}$ Radiation Oncology Department, Isola Tiberina Fatebenefratelli Hospital, Rome, Italy \\ ${ }^{\mathrm{m}}$ Radiation Oncology Department, University of Brescia and Spedali Civili, Brescia, Italy \\ ${ }^{\mathrm{n}}$ Radiation Oncology Department, Unit of University of Messina, Italy \\ ${ }^{\circ}$ Department of Human Pathology, University of Messina, Via Consolare Valeria n. 1, 98125 Messina, Italy \\ p Department of Radio-Oncology, Genolier Clinic, Genolier and Geneva, Switzerland \\ ${ }^{\mathrm{q}}$ Department of Oral and Maxillofacial Surgery, Academic Medical Center Amsterdam, University of Amsterdam, Amsterdam, The Netherlands \\ ${ }^{\mathrm{r}}$ Department of Medical Oncology, Universitair Ziekenhuis Antwerpen, Wilrijkstraat 10, 2650 Edegem, Belgium \\ ${ }^{\mathrm{s}}$ Division of Hematology/Oncology, Department of Medicine, Vanderbilt University, Nashville, TN, USA \\ ${ }^{\mathrm{t}}$ Department of Anesthesiology and Critical Care Medicine, University of Turin, S. Giovanni Battista-Molinette Hospital, Turin, Italy \\ u Cooper Medical School of Rowan University, Division of Critical Care Medicine, Cooper University Hospital, Camden, NJ, USA
}

Accepted 5 March 2015

\section{Contents}

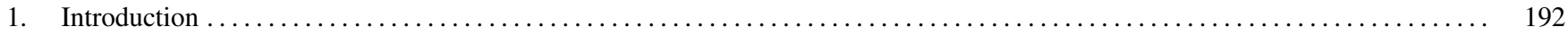

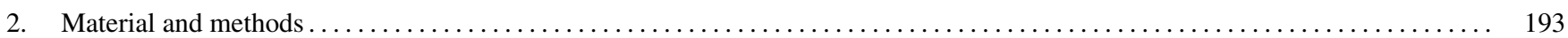

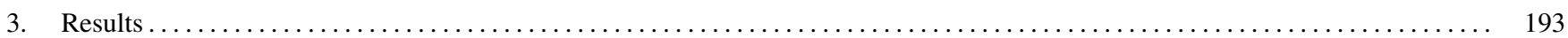

\footnotetext{
* Corresponding author. Tel.: +39 3280971299 .

E-mail addresses: aurora.mirabile@gmail.com (A. Mirabile), gnumico@ausl.vda.it (G. Numico), elviorussi@gmail.com (E.G. Russi), paolo.bossi@istitutotumori.mi.it (P. Bossi), fulvio.crippa@unimi.it (F. Crippa), almalina.bacigalupo@hsanmartino.it (A. Bacigalupo), vitaliana.desanctis@uniroma1.it (V. De Sanctis), musso.s@ospedale.cuneo.it (S. Musso), anna.merlotti@virgilio.it (A. Merlotti), mariagraziaghi@yahoo.it (M.G. Ghi), mcmerlano@gmail.com (M.C. Merlano), Lisa.Licitra@istitutotumori.mi.it (L. Licitra), moretto.francesco@ hotmail.it (F. Moretto), nerinadenaro@gmail.com (N. Denaro), Fabriori@libero.it (O. Caspiani), michela.buglione@unibs.it (M. Buglione), stpergolizzi@unime.it (S. Pergolizzi), acascio@unime.it (A. Cascio), jbernier@genolier.net (J. Bernier), jraber@worldonline.nl (J. Raber-Durlacher), janb.vermorken@uza.be (J.B. Vermorken), barbara.murphy@vanderbilt.edu (B. Murphy), Marco.ranieri@unito.it (M.V. Ranieri), Dellinger-Phil@CooperHealth.edu (R.P. Dellinger).
} 


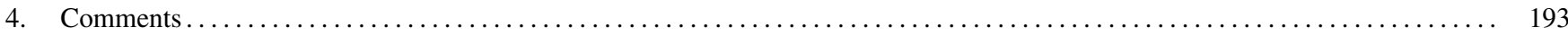

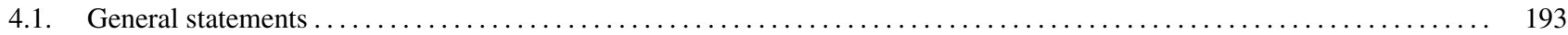

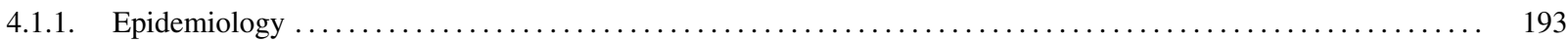

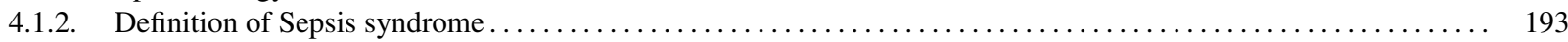

4.1.3. Etiology and pathogenesis of systemic inflammatory response syndrome (SIRS) and Sepsis in HNCPs....... 195

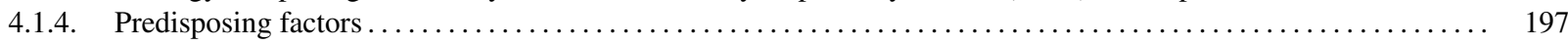

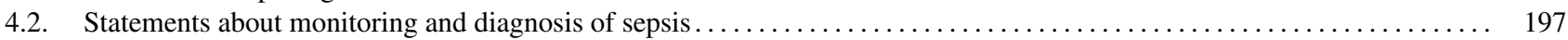

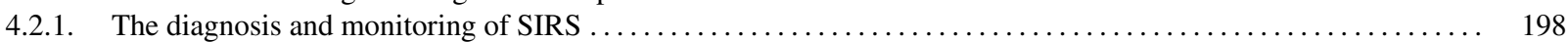

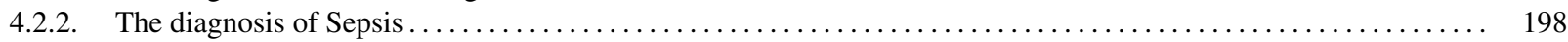

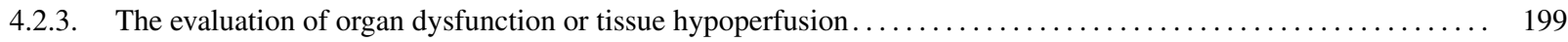

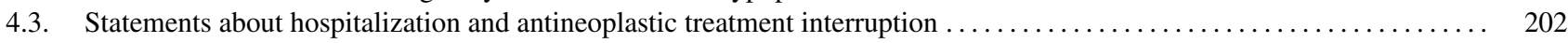

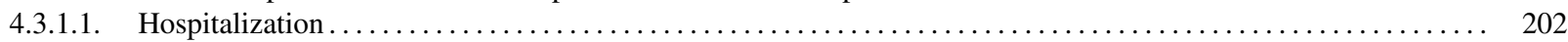

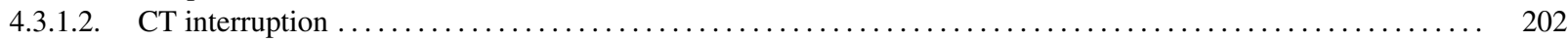

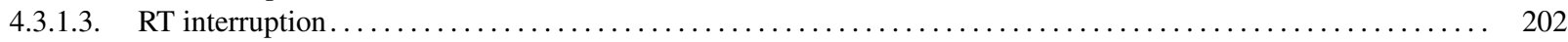

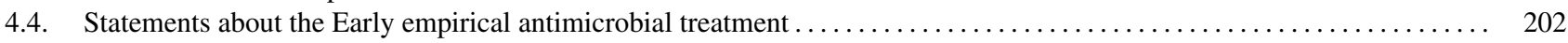

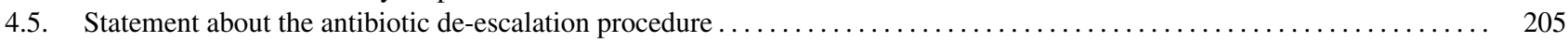

4.5.1. The empirical treatment must be optimized when microbiology results are available $\ldots \ldots \ldots \ldots \ldots \ldots \ldots$

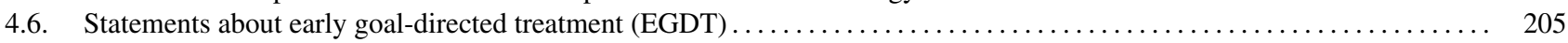

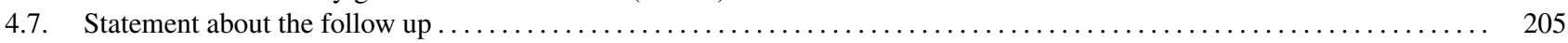

4.7.1. Monitoring for SIRS parameters should be continued after the end of CRT until the complete resolution of acute toxicities. Indeed, mortality for pneumonia is reported to occur well after 30 days from the end of treatments and

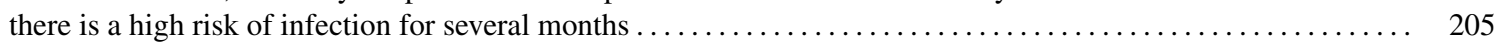

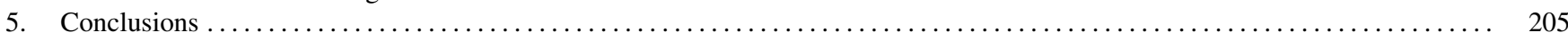

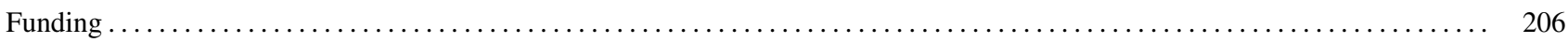

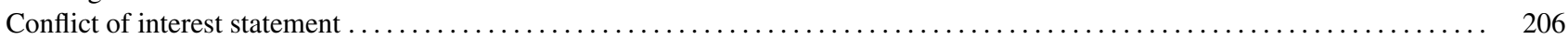

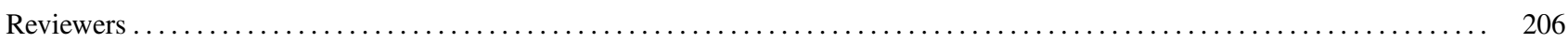

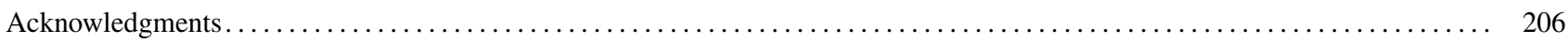

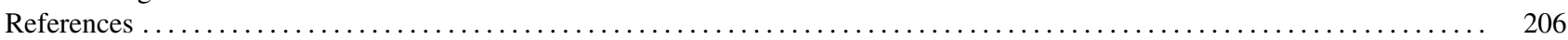

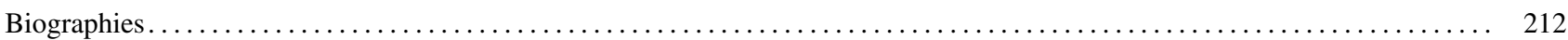

\begin{abstract}
The reporting of infection/sepsis in chemo/radiation-treated head and neck cancer patients is sparse and the problem is underestimated. A multidisciplinary group of head and neck cancer specialists from Italy met with the aim of reaching a consensus on a clinical definition and management of infections and sepsis. The Delphi appropriateness method was used for this consensus. External expert reviewers then evaluated the conclusions carefully according to their area of expertise. The paper contains seven clusters of statements about the clinical definition and management of infections and sepsis in head and neck cancer patients, which had a consensus. Furthermore, it offers a review of recent literature in these topics.
\end{abstract}

(C) 2015 Elsevier Ireland Ltd. All rights reserved.

Keywords: Sepsis; Head and neck cancer; Radiotherapy; Chemotherapy

\section{Introduction}

Chemo-radiotherapy (CRT) has increased the curability of locally advanced head and neck cancer patients (HNCPs) [1] and has allowed organ and function preservation in laryngeal and hypo-pharyngeal cancer patients [2]. However, competing causes of mortality (e.g. acute and late toxicities) are increased and substantially reduce the overall survival benefit $[3,4]$.

In CRT trials the acute mortality is described in the range from $2 \%$ [5] to $9.3 \%$ [6]. Infection is one of the main causes of acute mortality $[6,7]$.

Unfortunately, the reporting of infection is sparse even in randomized trials and the problem is likely underestimated.
There are three main limitations in interpreting data from CRT trials:

(1) Infection-related mortality can be confounded with other potential causes of death or categorized as "due to an unknown cause" [6], as the recognition of sepsis requires an active search and finite criteria. Most importantly unexplained organ failure (renal, respiratory, cardiovascular, coagulation, multi-organ etc.) is often reported as the cause of death while the probable relationship with underlying sepsis syndrome is not recognized.

(2) Organ damage due to the systemic inflammatory response is often misinterpreted as being related to the individual toxicities of the treatment. In a retrospective 
analysis of 394 patients enrolled in consecutive CRT phase II trials at the University of Chicago, 14 deaths were attributed to infection and eight cases of pneumonia were considered "comorbidities" [6]. In total, 22 deaths (5.6\%) were certainly due to infectious complications. Another 10 deaths were classified as due to "unknown reasons" or due to factors that could possibly be related to sepsis (small bowel necrosis, cardiac causes, "other respiratory disease" etc.). In addition, only recently have the abscopal effects of local inflammation toxicity been described [8-10]. Treatments enhancing local toxicity seem to be related to a higher degree of severe complications and deaths [11].

(3) Finally, the infectious-related mortality is not limited to the time of CRT administration but can occur several weeks after treatment [12]. Post-treatment infections and deaths are usually not considered treatment-related.

We feel that the lack of recognition of the connection between the single toxicities and the systemic consequences is due to insufficient knowledge about infection, sepsis and its sequelae. The definitions of these conditions have been evolving over the last 20 years. Consequently, the various specialists, such as medical oncologists (MOs), radiation oncologists (ROs), infectious disease physicians (IDPs) and critical care physicians (CCPs) treating HNCPs, use the terminology with different meanings. In fact, while years ago (before 1989) the term sepsis referred solely to a severe bacterial infection and was often confused with the infection itself, more recently sepsis has been defined as a systemic syndrome $[13,14]$ that encompasses multiple signs and symptoms resulting from the body's reaction to infectious systemic immune responses $[15,16]$. Helpful to the understanding of sepsis is the definition of the Systemic Inflammatory Response Syndrome (SIRS), indicating the unique, highly preserved systemic response to tissue damage (either infectious or non-infectious) $[14,17]$.

For all these reasons MOs, ROs, CCPs and IDPs from Italy met in Milan from February 17-18, 2013 with the aim of reaching a consensus on a clinical definition and management of infections and sepsis in CRT-treated HNCPs.

The results of the literature review and the statements that obtained consensus are reported and discussed in this paper.

\section{Material and methods}

The Delphi appropriateness method was used for this Consensus [18].

The panel, a group of 37 multidisciplinary experts (MOs, ROs, IDPs, CCPs, nutritionists and nurses), met in Milan from February 17-18, 2013 and appointed a facilitator board of 12 expert members, from different clinical settings (6 MOs, 4 ROs and 1 IDP and $1 \mathrm{CCP}$ ). The facilitator board performed a systematic review of the literature on infection in CRT-treated HNCPs.
The MEDLINE database was searched for Englishlanguage studies published from 1992 to March 2013 containing the terms sepsis, head and neck cancer, nosocomial, healthcare-acquired, infections, chemotherapy (CT), and radiotherapy (RT).

Potentially relevant abstracts presented at annual meetings of the American Society of Clinical Oncology and of the European Society of Medical Oncology were examined. The study selection included the following: (a) observational and prospective studies about assessment and treatment; (b) randomized, double-blind, placebo-controlled, or uncontrolled studies; (c) retrospective and uncontrolled studies; (d) systematic reviews and meta-analyses; (e) consensus guidelines. Furthermore, the electronic search results were supplemented by manual examination of reference lists from selected articles.

On the basis of this literature review, the facilitators identified a number of key statements.

All the experts rated these statements through a two-round process. A 4-grade scale was used, where 1 was defined as high consensus, 2 was defined as low consensus, 3 was defined as no consensus, and 4 was chosen by panelists when they felt unable to express an opinion.

A web meeting was held before the second rating, where statements were discussed. The statements that received a weak approval $(<75 / 100)$ were redefined according to the observations of panelists. The second ratings were analyzed to identify the statement that reached a consensus.

Each expert (including facilitators) was equally weighted in scoring the statements.

External MOs (JBV, BM), RO (JB), IDP (AC), supportive cancer care specialist (JR-D), and CCPs (MVR and RPD) reviewed the statements.

The panelists had a second meeting in Milan on May 5, 2014 in order to approve the final version of the statements.

\section{Results}

Consensus-reached statements are listed in Table 1.

\section{Comments}

\subsection{General statements}

\subsubsection{Epidemiology}

The rate of infection during CRT is around 19\%, the acute mortality of CRT is between $2 \%$ and $9.3 \%$ and the majority of deaths occurring within 30 days from the end of treatment is infection-related.

\subsubsection{Definition of Sepsis syndrome}

The panel adopted the nomenclature and definitions for terms used by 2001 International Sepsis Definitions 
Table 1

Consensus-reached statements.

\begin{tabular}{ll}
\hline Cluster Phase & Descritpion \\
\hline 1 Before CRT & General statements \\
& 1.1 Epidemiology: The rate of infection during CRT is around $19 \%$ [5,151-156], the acute \\
& mortality of CRT is between $2 \%$ [5] to 9.3\% [6], and the majority of deaths occurring within \\
& 30 days from the end of treatment is infection-related \\
& 1.2 Definition of Sepsis syndrome: The panel adopted the nomenclature and definitions for \\
& terms used by 2001 International Sepsis Definitions Conference (i.e. SIRS, sepsis, severe \\
& sepsis, and septic shock) (see Table 2) [23] \\
& 1.3 Etiology and pathogenesis of systemic inflammatory response syndrome (SIRS) and \\
& Sepsis in HNCPs: any kind of tissue damage can induce a SIRS through circulating \\
& mediators. When this response is prolonged and associated with infection it can result in \\
& severe sepsis and its complications [19,44]. \\
& 1.4 Predisposing Factors. HNCPs with habits such as smoking [46,47] and alcohol [48] \\
& consumption, malnutrition [82,157], swallowing impairment with aspiration [45], \\
chemotherapy-induced neutropenia [39,158,159], disruption of physiological barriers as a \\
consequence of radiodermitis and mucositis [40,160], gingival pockets and dental caries \\
[161-164], age [12,165,166], co-morbidities such as diabetes and chronic obstructive \\
pulmonary disease (COPD) [166], and the presence of central venous catheters, gastrostomy \\
and tracheostomy are at a higher risk of infections.
\end{tabular}

2 during CRT Statements about Monitoring and Diagnosis of Sepsis.

.2.1. The diagnosis and monitoring of SIRS:

2.1.1 SIRS should be assessed at least weekly in all HNCPs undergoing CRT through vital parameter monitoring (blood pressure, heart rate, respiratory rate, and digital oxymetry etc.), and white blood cell count.

.2.2. The diagnosis of Sepsis

.2.2.1 In the case of SIRS, the search for an associated infection should be rapidly performed through clinical examination, radiological imaging, blood cultures, and culture from the suspected sites of infection (urine, sputum, stools, needle aspirate or swabs of skin lesions). Unfortunately, positive cultures are obtained only in one third of cases and their negativity does not rule out the presence of infection (mainly due to concomitant antibiotic use, inadequacy of samples sent to the microbiology laboratory).

.2.2.2 Mandatory cultures of all suspected sites of infection and radiological imaging should be performed before the start of antibiotic treatment in order to improve the rate of etiologic diagnosis.

2.2.3 C-Reactive Protein (CRP) and/or procalcitonin and plasma lactate can add useful information about infection diagnosis, hence these blood levels may be considerd in case of suspected infection.

.2.3. The evaluation of organ dysfunction or tissue hypoperfusion

2.3.1 The evidence for organ dysfunction or tissue hypoperfusion should be accomplished with urine input/output evaluation, serum lactate, full biochemistry (with renal and liver function tests, coagulation), and arterial blood gas analysis.

3 during CRT Statements about Hospitalization and antineoplastic treatment interruption .3.1. Hospitalization: HNCPs with sepsis should be promptly hospitalized as this condition can progress rapidly

.3.2. CT interruption: For suspected or confirmed severe sepsis during CRT, CT should be the first treatment to be interrupted.

3.3. RT interruption: For suspected or confirmed sepsis during CRT, RT should be stopped only in particularly compromised patients or in the presence of severe sepsis.

4 during CRT Statements about the Early Empirical Antimicrobial treatment

.4.1. Empirical antibiotic therapy should be started within $3 \mathrm{~h}$ of clinical presentation [70]

4.2. For suspected or confirmed sepsis (systemic inflammatory response to infection; see Table 2) empirical antibiotic therapy should be started, considering both anti Gram+ and anti Gram- antibiotics $[108,109]$. It should attempt to provide antimicrobial activity against the most likely pathogens based upon the potential source of infection searched on the basis of each HNCP's presenting illness

.4.3. Empirical antibiotic therapy has to be based on local surveillance, antibiotic sensitivity and infection rate/prevalence; otherwise a rational use of antibiotics in accordance with international guidelines is advisable (e.g. Centers for Disease Control and Prevention CDC)

Clinical Oncologist and nurse

Clinical Oncologist and nurse

Clinical Oncologist and nurse

Clinical Oncologist and nurse

Clinical Oncologist and nurse

Clinical Oncologist, $80 \%$ nurse and patient

Clinical Oncologist and nurse

Clinical Oncologist and nurse

Clinical Oncologist and nurse

Clinical Oncologist

Clinical Oncologist

Clinical Oncologist

Clinical Oncologist $100 \%$ and nurse Clinical Oncologist, Infectious Disease Physician and nurse

Clinical Oncologist, $80 \%$ 
Table 1 (Continued)

\begin{tabular}{|c|c|c|c|}
\hline Cluster Phase & Descritpion & $\begin{array}{l}\text { Whom is it in } \\
\text { charge of? }\end{array}$ & $\begin{array}{l}\text { The degree } \\
\text { of consensus }\end{array}$ \\
\hline & $\begin{array}{l}\text { 4.4. Considering the very high rate of infection sustained by multi- and pan- resistant } \\
\text { microorganisms in the HNCPs as well as in the general population, when local guidelines are } \\
\text { not available, it is suggested that treatment with broad spectrum, potent antibiotics active } \\
\text { against enterobacteriaceae and methicillin-resistant Staphylococcus aureus be started [108]. }\end{array}$ & $\begin{array}{l}\text { Clinical Oncologist } \\
\text { and Infectious } \\
\text { Disease Physician }\end{array}$ & $94 \%$ \\
\hline & $\begin{array}{l}\text { 4.5. In the presence of sepsis following an oral cavity infection, the treatment might consider } \\
\text { the introduction of an antifungal agent associated with an anti-Gram+ antibiotic }\end{array}$ & $\begin{array}{l}\text { Clinical Oncologist, } \\
\text { Infectious Disease } \\
\text { Physician and nurse }\end{array}$ & $82 \%$ \\
\hline & $\begin{array}{l}\text { 4.6. Once aspiration pneumonia is suspected, a low threshold for CT scan and diagnostic } \\
\text { bronchoscopy should be maintained. }\end{array}$ & $\begin{array}{l}\text { Clinical Oncologist, } \\
\text { Infectious Disease } \\
\text { Physician and nurse }\end{array}$ & $95 \%$ \\
\hline & $\begin{array}{l}\text { 4.7. For healthcare-associated infections non-responsive to the first line of antibiotics, the } \\
\text { IDPs' assessment is mandatory. }\end{array}$ & $\begin{array}{l}\text { Clinical Oncologist, } \\
\text { Infectious Disease } \\
\text { Physician and nurse }\end{array}$ & $100 \%$ \\
\hline 5 during CRT & $\begin{array}{l}\text { Statement about the antibiotic de-escalation procedure: } \\
\text { 5.1. The empirical treatment must be optimized when microbiology results are available. }\end{array}$ & $\begin{array}{l}\text { Clinical Oncologist, } \\
\text { Infectious Disease } \\
\text { Physician }\end{array}$ & $100 \%$ \\
\hline \multirow{2}{*}{ : } & Statements about Early Goal-Directed Treatment (EGDT) & & \\
\hline & $\begin{array}{l}\text { 6.1. In cases of severe sepsis (sepsis + organ failure) supportive therapy using the "EGDT" } \\
\text { scheme should be applied as soon as possible: oxygen administration, hydration with } \\
\text { crystalloids and targeting a Svo } 2 \text { of } 70 \% \text {. } \\
\text { 6.2. Most patient with severe sepsis (see Table 4) should be rapidly referred to an intensive } \\
\text { care unit (ICU) }\end{array}$ & $\begin{array}{l}\text { Clinical Oncologist, } \\
\text { Infectious Desease } \\
\text { Physician. } \\
\text { Clinical Oncologist, } \\
\text { Infectious Disease } \\
\text { Physician and } \\
\text { Critical Care } \\
\text { Physician }\end{array}$ & $100 \%$ \\
\hline 7 After CRT & $\begin{array}{l}\text { Statement on the Follow up: } \\
\text { 7.1. Monitoring for SIRS parameters should be continued after the end of CRT until the } \\
\text { complete resolution of acute toxicities. Indeed, mortality for pneumonia is reported to occur } \\
\text { well after } 30 \text { days from the end of treatments and there is a high risk of infection for several } \\
\text { months }\end{array}$ & $\begin{array}{l}\text { Clinical Oncologist } \\
\text { and nurse }\end{array}$ & $95 \%$ \\
\hline
\end{tabular}

${ }^{\text {a }}$ Statements that do not need to be rated.

Conference (i.e. SIRS, sepsis, severe sepsis, and septic shock) (Table 2).

Before 1989 [13,14], "sepsis" was considered to be a systemic infection, often described as "blood poisoning" and assumed to be the result of the host's invasion by pathogenic organisms that then spread within the bloodstream. After the advent of modern antibiotics, germ theory could not fully explain the pathogenesis of sepsis: researchers suggested that it is the host, not the germ, that drives the pathogenesis of sepsis [19].

Recently a "Consensus conference" attempted to "provide a conceptual and practical framework to define the systemic inflammatory response to infection" [17]. The acronym SIRS (Systemic Inflammatory Response Syndrome) was used in order to provide a reference for the complex findings that result from a systemic activation of the immune response, triggered by a variety of infectious and noninfectious conditions. Yet, the identification of sepsis through the 1992-consensus SIRS criteria had a high sensitivity but a low specificity. Indeed, the same criteria can be found in non-infectious conditions [20] and may represent an appropriate physiological reaction [21,22]. In 2001 an International
Sepsis Definitions conference revisited the SIRS criteria (see Table 2) [23] by expanding the list of possible signs of systemic inflammation in response to infection to the physical and laboratory findings indicative of early organ dysfunction, altered tissue perfusion, and hemodynamic failure, as well.

Thus, even though the 1991 four criteria for sepsis continue to be used because they are easily measurable [24,25], in presence of suspected sepsis, the other items included in the 2001-consensus list in order that the presence of some degree of organ dysfunction, altered tissue perfusion, and/or hemodynamic failure have to be actively searched.

\subsubsection{Etiology and pathogenesis of systemic inflammatory response syndrome (SIRS) and Sepsis in HNCPS}

Any kind of tissue damage can induce a SIRS through circulating mediators. When this response is prolonged and associated with infection it can result in severe sepsis and related complications.

Recently the definition of immunity reactions has been revisited [26,27]: either endogenous danger signals (danger/damage-associated molecular patterns - DAMPs) 
Table 2

Nomenclature and definitions for terms used in critical illness.

\begin{tabular}{|c|c|}
\hline Nomenclature & Note \\
\hline Infection & $\begin{array}{l}\text { A microbial phenomenon } \\
\text { characterized by a local inflammatory } \\
\text { response to the presence of } \\
\text { microrganisms or the invasion of } \\
\text { normally sterile host tissue by those } \\
\text { organisms (or by their products) }\end{array}$ \\
\hline Bacteraemia & $\begin{array}{l}\text { The presence of viable bacteria in the } \\
\text { blood. The presence of viruses, } \\
\text { fungi, parasites should be described } \\
\text { in a similar manner (viremia, } \\
\text { fungemia, parasitemia) }\end{array}$ \\
\hline SIRS & $\begin{array}{l}\text { Symptoms and signs related to } \\
\text { panoply of non-specific } \\
\text { inflammatory response. }\end{array}$ \\
\hline
\end{tabular}

\begin{tabular}{ll} 
Clinical disease & Clinical signs \\
\hline Localized & Tumor, rubor, calor, dolor and function laesa
\end{tabular}

inflammation

Systemic Two or more:

Inflammatory $\quad-$ Temperature $>38^{\circ} \mathrm{C}$ or core temperature $<36^{\circ} \mathrm{C}$

Response Syndrome: - Heart rate $>90$ beats $/ \mathrm{min}$

Bone version 1991

[14] 11

- Respiratory rate $>20$ breaths $/ \mathrm{min}$ or $\mathrm{PaCO} 2<37 \mathrm{mmHg}$ or

mechanically ventilated

Sepsis $^{\mathrm{a}} \quad$ Systemic inflammatory response to infection.

Recently, some Authors [168] 28

have defined sepsis when organ

failures are documented

\section{Diagnostic criteria for}

- Leukocyte count $>12,000 / \mu l$ or $<4000 / \mu 1$

- Fever (core temperature $>38.3^{\circ} \mathrm{C}$ )

- Hypothermia (core temperature $<36^{\circ} \mathrm{C}$

- Heart rate $>90 \mathrm{bpm}$ or $>2$ SD above the normal value for age

- Tachypnea: $>30$ bpm

- Altered mental status

- Significant edema or positive fluid balance ( $>20 \mathrm{ml} / \mathrm{kg}$ over

$24 \mathrm{~h}$ )

- Hyperglycemia (plasma glucose $>140 \mathrm{mg} / \mathrm{dl}$ or $7.7 \mathrm{mM} / \mathrm{l}$ ) in

the absence of diabetes

Inflammatory parameters

- Leukocytosis (white blood cell count $>12,000 / \mu \mathrm{l}$ )

- Leukopenia (white blood cell count $<4000 / \mu \mathrm{l}$ )

- Normal white blood cell count with $>10 \%$ immature forms

- Plasma $\mathrm{C}$ reactive protein $>2 \mathrm{SD}$ above the normal value

- Plasma procalcitonin $>2$ SD above the normal value

Hemodynamic parameters

- Arterial hypotension (systolic blood pressure $<90 \mathrm{mmHg}$, mean arterial pressure $<70 \mathrm{mmHg}$, or a systolic blood pressure decrease $>40 \mathrm{mmHg}$ in adults or $<2 \mathrm{SD}$ below normal for age)

- Mixed venous oxygen saturation $>70 \%$

- Cardiac index $>3.51 \mathrm{~min}$

Organ dysfunction parameters

- Arterial hypoxemia $\left(\mathrm{PaO}_{2} / \mathrm{FIO}_{2}<300\right)$

- Acute oliguria (urine output $<0.5 \mathrm{~mL} / \mathrm{kg} / 1 \mathrm{~h}$ or $45 \mathrm{mM} / \mathrm{l}$ for at least $2 \mathrm{~h}$ )

- Creatinine increase $\geq 0.5 \mathrm{mg} / \mathrm{dl}$

- Coagulation abnormalities (international normalized ratio

$>1.5$ or activated partial thromboplastin time $>60 \mathrm{~s}$ )

- Ileus (absent bowel sounds)

- Thrombocytopenia (platelet count $<100,000 / \mu 1$ )

- Hyperbilirubinemia (plasma total bilirubin $>4 \mathrm{mg} / \mathrm{dl}$ or

$70 \mu \mathrm{mol} / \mathrm{l})$

Tissue perfusion parameters

- Hyperlactatemia (>1 $\mu \mathrm{mol} / \mathrm{l})$

- Decreased capillary refill or mottling

Severe Sepsis (Sepsis

with organ

dysfunction $)^{\mathrm{a}}$
Symptoms and signs related to panoply of nonspecific inflammatory response and to dysfunctions of organs and of microvasculature.
Deteriorating

evolution of systemic inflammation
Sepsis + organ dysfunctions (due to abnormal organ perfusion) in acutely ill patients

Sepsis + refractory (unresponsive to fluid and vasopressors) hypotension+ perfusion abnormality

\footnotetext{
${ }^{a}$ Septicaemia was the archaic term to identify these syndromes.
} 


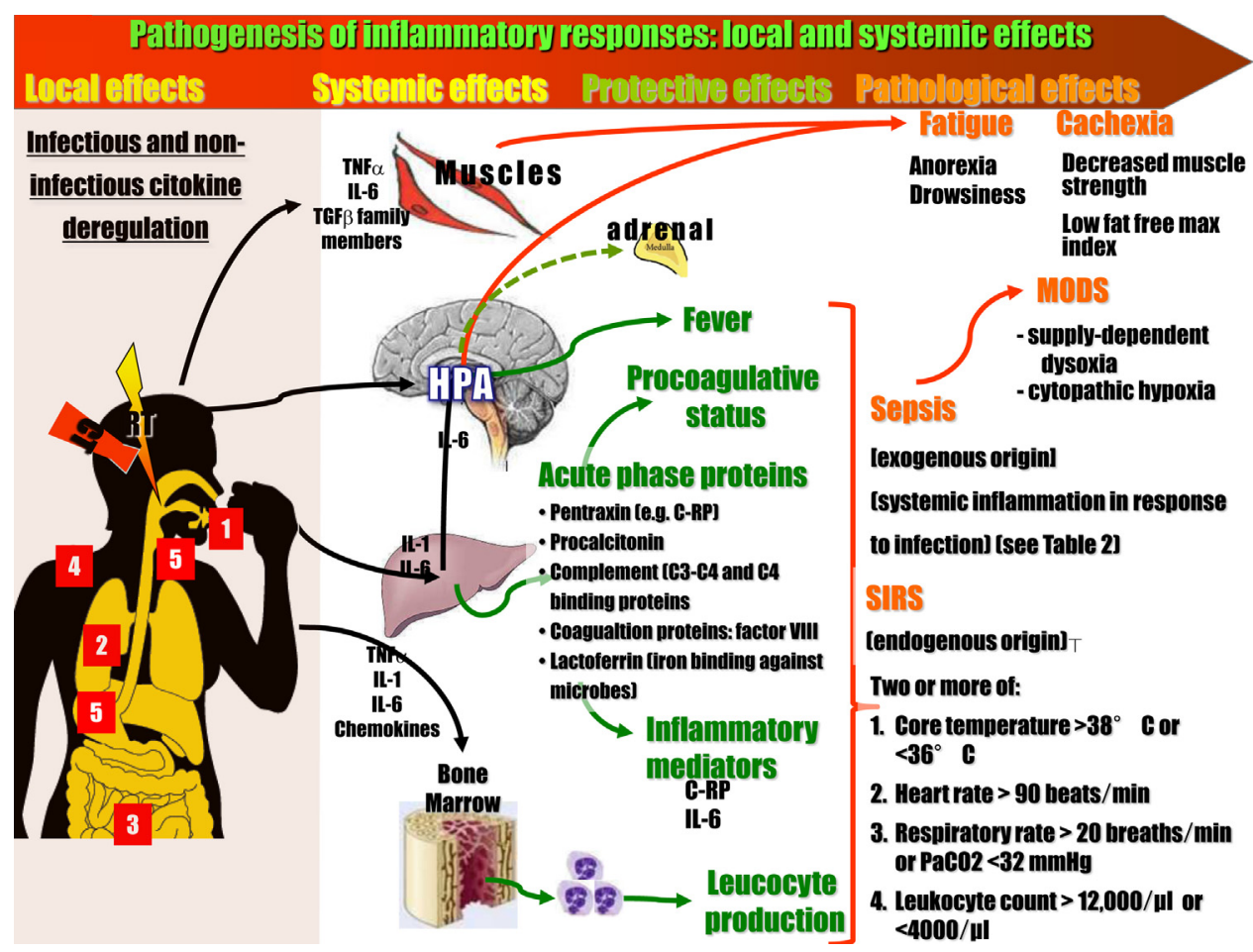

Fig. 1. Pathogenesis of inflammatory responses: local and systemic effects [20]. Legend: radiochemotherapy on the treated tissues causes damage that facilitates inflammation. Furthermore germs may more easily spread via the bloodstream after translocation through disrupted barriers: (1) mouth, (2) respiratory tract, (3) intestinal mucosa, (4) skin and (5) devices. Released cytokines act not only locally but also on other organs and tissues (Inter-organ signaling). On muscles they can alter energetic metabolism (thus favoring cachexia). On HPA (hypothalamic-pituitary-adrenal axis) they cause fever and fatigue symptoms. On the liver they provoke the synthesis of acute phase proteins that in turn act in a procoagulative and general inflammatory and anti-inflammatory sense. All these effects can lead to systemic inflammatory response syndrome (SIRS) or sepsis. Abbreviations: $\mathrm{PaCO}_{2}=$ arterial carbon dioxide tension; MODS: Multi-organ Dysfunction Syndrome; Other abbreviations see the text.

$[28,29]$, generated by stressed host cells, or exogenous pathogen-associated molecular patterns (PAMPs) [30-32] are recognized as being capable of activating the pattern recognition receptors (PRRs) [33] of the immune cells and as promoting the synthesis of inflammation mediators. Thus, any kind of tissue damage (pathogens [34,35], CRT [8,9] etc.) can induce a local $[27,36]$ and systemic inflammatory response through circulating mediators (Fig. 1) $[8,9,20]$. Some Authors [37] postulated that anti-inflammatory mediators predominate within the bloodstream to avoid igniting new inflammatory foci, while their presence within tissues may not always be sufficient to prevent the initiation of a deleterious inflammatory response in various compartments [38]. Consequently, the sepsis/SIRS-patient plasma behaves as an immunosuppressive milieu [39]. A consequence of this deregulation is the fact that germs may more easily spread via the bloodstream after translocation through disrupted barriers (skin and mucosal barrier injury [40]).

Thus, it has become apparent that when prolonged or intensive host responses are provoked (infections, trauma, or CRT) [41-43] both pro-inflammatory and anti-inflammatory mechanisms (involving cytokines) can contribute to infection clearance, organ injury and secondary infections [44] (Fig. 1). During CRT, HNCPs have a number of conditions predisposing to infection [45], making them extremely at risk.

\subsubsection{Predisposing factors}

HNCPs with habits such as smoking [46,47] and alcohol [48] consumption, malnutrition, swallowing impairment with aspiration, chemotherapy-induced neutropenia, disruption of physiological barriers as a consequence of radiodermitis and mucositis, gingival pockets and dental caries, age, co-morbidities such as diabetes and chronic obstructive pulmonary disease (COPD), and the presence of central venous catheters, gastrostomy and tracheostomy are at a higher risk of infections.

\subsection{Statements about monitoring and diagnosis of sepsis}

The early identification of sepsis and implementation of early therapies have been documented to improve outcomes and decrease sepsis-related mortality [49]. Reducing the time to diagnosis of severe sepsis is thought to be a critical component of reducing mortality from sepsis-related multiple organ dysfunction [50]. As oncological patients with sepsis are logically not different from other septic patients, the panel recommends an early diagnosis of sepsis by following the three main steps: 
Table 3

Infection probability score $^{\mathrm{a}}$ (IPS) [51].

\begin{tabular}{|c|c|c|c|c|c|c|c|}
\hline & 0 & 1 & 2 & 3 & 6 & 8 & 12 \\
\hline Body temperature $\left({ }^{\circ} \mathrm{C}\right)$ & $\leq 37.5$ & & $\geq 37.5$ & & & & \\
\hline Heart rate (beats/min) & $\leq 80$ & & & & & $81-140$ & $>140$ \\
\hline Respiratory rate (breaths/min) & $\leq 25$ & $>25$ & & & & & \\
\hline White Blood Cell $\left(\times 10^{3} / \mathrm{mm}^{3}\right)$ & $5-12$ & $>12$ & & $<5$ & & & \\
\hline C-RP (mg/dL) & $\leq 6$ & & & & $>6$ & & \\
\hline SOFA $^{\mathrm{b}}$ score (see Table 4$)$ & $\leq 5$ & & $>5$ & & & & \\
\hline
\end{tabular}

a Patients with a score $<14$ points have only a $10 \%$ risk of infection.

b Sequential organ failure assessment.

1. Diagnosis and monitoring of SIRS.

2. Diagnosis of Sepsis.

3. Evaluation for organ dysfunction or tissue hypoperfusion.

\subsubsection{The diagnosis and monitoring of SIRS}

4.2.1.1. SIRS should be assessed at least weekly in all HNCPs undergoing CRT through vital parameter monitoring (blood pressure, heart rate, respiratory rate, and digital oxymetry etc.), and white blood cell count. SIRS parameters need monitoring. Indeed, even if the finding of two positive SIRS parameters is not specific, it may help physicians to graduate the urgency of intervention, to promptly activate the search for infection, and to shorten the time to start antibiotic administration. In addition, it is suggested that other diagnostic parameters for sepsis, such as those suggested by the 2nd consensus conference [23], be performed as a regular procedure [22].

Another important role of the assessment of SIRS criteria can be the evaluation of patients with local tissue damage or infection. In CRT-treated HNCPs the occurrence of stomatitis, in-field skin toxicity, or device-related skin infection can be either a local limited phenomenon or a systemic evolving response [20]. The latter deserves a timely application of systemic treatment. Thus, more frequent analysis (at least daily) of SIRS criteria has the potential of capturing the systemic evolution of a local inflammation and of orienting all the following management strategies.

Recently, Peres Bota et al. [51] developed an infection probability score (IPS) which uses six variables (Table 3) to assess the likelihood of infection, resulting in a score from 0 to 26: the 14 score cut-off proved to be reliable enough (positive predictive value $=53.6 \%$; negative predictive value $=89.5 \%$ ) in distinguishing infectious $(\geq 14)$ from non-infectious $(<14)$ SIRS. In addition, changes in IPS over time may be useful in following the response to antimicrobial therapy [52].

\subsubsection{The diagnosis of Sepsis}

4.2.2.1 In the case of SIRS, the search for an associated infection should be rapidly performed through clinical examination, radiological imaging, blood cultures, and culture from the suspected sites of infection (urine, sputum, stools, needle aspirate or swabs of skin lesions). Unfortunately, positive culture results are obtained only in one third of cases and their negativity does not rule out the presence of infection (mainly due to concomitant antibiotic use, inadequacy of samples sent to the microbiology laboratory)

4.2.2.2 Mandatory cultures of all suspected sites of infection and radiological imaging should be performed before the start of antibiotic treatment in order to improve the capability to achieve etiologic diagnosis

4.2.2.3 C-Reactive Protein (CRP) and/or procalcitonin and plasma lactate can add useful information about infection diagnosis, hence these blood levels may be considered in case of suspected infection

The first step in assessing the patient with suspected sepsis is to determine the actual risk of infection and the likely source by obtaining information regarding colonizing or infecting pathogens: the nature of any localizing symptoms and signs should be noted. At any rate, the altered immune function may not present the typical sign of inflammation and may occult the localizing signs. Thus, any suspected source must be examined (skin, presence of devices, leg thrombosis, neck, mucosae and lungs.)

SIRS-positive HNCPs should undergo laboratory, microbiological, and radiological evaluation after an infection probability assessment based on history and physical examination.

- Laboratory evaluation

- Thrombocytosis, thrombocytopenia, hyperglycemia, metabolic acidosis, and changes in the inflammatory status. Even though TNF, IL-1, IL-6, IL-8, and IL-10 are all important in sepsis, they are not specific for inflammation/organ dysfunction, and do not assist in distinguishing between infectious and non-infectious causes.

- C-Reactive Protein (C-RP) and/or procalcitonin, although not always associated with infection [53-58], can add useful information about its diagnosis.

- C-RP levels $>17 \mathrm{mg} / \mathrm{dl}$ have been suggested as providing a means of separating patients with sepsis from those with non-septic inflammatory response due to other causes (e.g. trauma)[59].

- Procalcitonin has been proposed as a marker of infection [60-63]. Furthermore, it may be useful as an indicator of the severity of infection and as a guide for therapy (dose de-escalation [64]) in respiratory infections [61,62,65-68].

Thus, these markers cannot be recommended distinguishing between severe infection and other acute inflammatory 
states [69], but they can be helpful adjunctive diagnostic markers to be interpreted in context with information from careful medical history, physical examination.

- Microbiological evaluation:

Obtaining cultures before antimicrobial administration is essential to confirm infection, to appropriately target antibiotic therapy and to allow antimicrobial de-escalation after receipt of the susceptibility profile [70]. Unfortunately, positive results are obtained only in one third of the cases and their negativity does not rule out the presence of infection [71]. Considering that the first antimicrobial dose can rapidly sterilize blood cultures within a few hours, obtaining those cultures before therapy is essential. Thus, at least two blood cultures, both peripherally and via indwelling catheters are recommended [70,72-74]. Although some guidelines [70] recommend that cultures should not cause significant delay (>45 min) in starting antimicrobial administration, some authors suggest that non-neutropenic and stable patients should be observed without empirical antibiotics while considering further diagnostic evaluation [75].

If fungal infection is suspected, 1-3b-D-glucan, mannan and anti-mannan antibody assays have shown positive results significantly earlier than with standard culture methods [70]. False positive reactions can occur with colonization alone [76].

Microbiological samples should also be taken from sites that are suspected of being infected.

- Radiological evaluation:

In order to identify the infection sources, imaging may help. Ultrasonography, performed at the bedside, can assist in localizing a fluid collection and may allow for percutaneous drainage and microbial cultures. CT scanning can help identify thoracic, abdominal, and deep-space infections. White Indium 111 -labeled blood-cell scans and indium $_{111}$ Immunoglobulin-G have poor sensitivity and specificity, whereas Technetium scans seems to be more useful, owing to its high specificity (93-94\%), but it has a poor sensitivity (40-75\%) [77]. Finally, Fluorodeoxyglucose positron-emission tomography (FDG-PET) scans have a high sensitivity (95\%) and a good specificity (88\%) in identifying septic sources in patients with fever of unknown origin [77-79].

\subsubsection{The evaluation of organ dysfunction or tissue hypoperfusion}

4.2.3.1. The evidence for organ dysfunction or tissue hypoperfusion should be accomplished with urine input/output evaluation, serum lactate, full biochemistry (with renal and liver function tests, coagulation), and arterial blood gas analysis. Sepsis and non-infectious SIRS can induce the MODS. The number of organ failures during sepsis increases the risk of mortality [80-82]. Thus, assessment of bone marrow, renal, liver, brain, coagulation, respiratory and circulatory functions through laboratory examinations and clinical monitoring should always be associated with the search for the infection site (Table 4).
The term "severe sepsis" was proposed to describe instances in which sepsis is complicated by inadequate tissue perfusion or organ dysfunction [83]. Capillary bed hypo-perfusion causes dysoxia, due to both altered microcirculation ("supply-dependent dysoxia") [83,84] and the inhibition of mitochondrial respiratory enzymes caused by toxic oxygen and nitrogen intermediates ("cytopathic hypoxia") $[85,86]$.

Other causes of peripheral hypoxia are the myocardial contractility depression, owing to a variety of myocardial depressants found in the septic-patient plasma (such as TNFa, IL-1, IL-6 and nitric oxide) [87,88], and the acute lung injury due to damage to the pulmonary vascular circulation and the alveolar-capillary membranes.

As a consequence of the above-mentioned causes, the circulatory abnormalities (intravascular volume depletion, peripheral vasodilatation, myocardial depression) and increased metabolism lead to an imbalance between systemic oxygen delivery/demand, resulting in global tissue hypoxia or even shock. As the cardiovascular system is designed to preserve arterial blood pressure to maintain cerebral and coronary perfusion during stress by reducing perfusion to peripheral tissues, the routine vital signs, central venous pressure and urinary output $[89,90]$ may be relatively insensitive measures of early circulatory shock (also known as "cryptic shock" [90]), whereas serum lactate levels can serve as a marker of occult hypoperfusion [91,92]. Indeed, patients with cryptic hypoperfusion are often overlooked as candidates for aggressive interventions because they are hemodynamically stable [93], but they are associated with increased mortality [92,94-97]. Thus, the main endpoint in sepsis treatment is to recognize the imbalance between oxygen delivery/demand measuring serum lactate in order to start resuscitation promptly [70,93] (the so called Early Goal directed therapy (EGDT)). Current critical care guidelines recommend measuring serum lactate in hemodynamicallystable patients with sepsis to assess for occult hypoperfusion, since an elevated lactate level ( $\geq 4 \mathrm{mmol} / \mathrm{L})$ may warrant ICU transfer. Recent evidence (non-randomized trials) suggests that the serum lactate threshold used to identify patients eligible for EGDT be lowered, given the association between modestly elevated serum lactate levels $(\geq 2 \mathrm{mmol} / \mathrm{L})$ and morbidity and mortality [70,96,97]. This transition point (lactate $\geq 2 / 4 \mathrm{mmol} / \mathrm{L}$ ) occurs during the critical "golden hours" when treatment can provide maximum benefits in terms of outcome [93]. Thus, EGDT policy aims to restore this balance promptly by manipulating cardiac contractility, oxygenation, and tissue perfusion.

The parameters that monitor this balance between oxygen delivery/demand include mixed oxygen saturation (pulmonary-artery oxyhemoglobin saturation representing total balance of oxygen consumption and delivery assuming ability of cells to take up oxygen) $\left(\mathrm{SvO}_{2}\right)$ or central venous saturation $\left(\mathrm{ScvO}_{2}\right)$ (superior half-body oxygen saturation), lactate production, base deficit and $\mathrm{pH}$ [98]. Yet, one of the problems in the applicability of these guidelines is the need 
Table 4

The goal of supportive treatment: restoration and maintenance of adequate tissue perfusion so as to prevent multiple organ dysfunctions.

\begin{tabular}{|c|c|c|c|c|}
\hline Goal & Clinical manifestation & Monitoring & Action & Warning \\
\hline \multicolumn{5}{|c|}{ Hemodinamic support (Early Goal Directed therapy) } \\
\hline $\begin{array}{l}\text { Tissue } \\
\quad \text { Oxygenation/perfusion: }\end{array}$ & $\begin{array}{l}\text { Early recognition of the imbalance } \\
\text { between oxygen delivery and oxygen } \\
\text { demand measuring serum lactate and } \\
\text { oxygen saturation }\end{array}$ & $\begin{array}{l}\text { lactate level }>2 \mathrm{mmol} / \mathrm{L} \text {. } \\
\text { maintain } \mathrm{O}_{2} \text { sat }>90 \% \text { or } \mathrm{PaO}_{2}>60 \mathrm{mmHg} \\
\text { Monitor volume overload }(\mathrm{VoL})^{\mathrm{a}} \text {. }\end{array}$ & $\begin{array}{l}\text { Fluid resuscitation: Administer } 30 \mathrm{ml} / \mathrm{kg} \\
(0.9 \% \text { sodium chloride or lactated } \\
\text { Ringer) crystalloid for hypotension or } \\
\text { lactate } \geq 2 / 4 \mathrm{mmol} / \mathrm{L}\end{array}$ & $\begin{array}{l}\text { After }>4 \mathrm{~L} \text {, if there is } \\
\text { no improvement }{ }^{\mathrm{b}} \text { or if } \\
\text { there is evidence of } \\
\text { volume overload in } \\
\text { ICU for vasopressor } \\
\text { therapy }\end{array}$ \\
\hline
\end{tabular}

Monitor and support MODS

Respiratory [170] No Dysfunction

ALI or mild ARDS

Moderate ARDS

Severe ARDS

Cardio vascular

No hypotension

Hypotension

Renal dysfunction

Decreased UOP

Coagulopathy

DIC and Bleeding

Central nervous system

GCS testing:

Eye, Verbal and motor responses
SOFA scale [169]

$\mathrm{PaO}_{2} / \mathrm{FiO}_{2}>400 \mathrm{~mm} \mathrm{Hg}$

$\mathrm{PaO}_{2} / \mathrm{FiO}_{2}<400 \mathrm{~mm} \mathrm{Hg}$

$\mathrm{PaO}_{2} / \mathrm{FiO}_{2}<300 \mathrm{~mm} \mathrm{Hg}$

$\mathrm{PaO}_{2} / \mathrm{FiO}_{2}<200 \mathrm{~mm} \mathrm{Hg}$ $\mathrm{PaO}_{2} / \mathrm{FiO}_{2}<100 \mathrm{~mm} \mathrm{Hg}$

$\mathrm{MAP} \geq 70 \mathrm{mmHg}$

MAP $<70 \mathrm{mmHg}$

Dobutamine any dose or Dopamine $\leq 5 \mu \mathrm{g} / \mathrm{kg} / \mathrm{min}$

Dopamine $>5 \mu \mathrm{g} / \mathrm{kg} / \mathrm{min}$ or epinephrine or

norepinephrine $\leq 0.1 \mu \mathrm{g} / \mathrm{kg} / \mathrm{min}$

Dopamine $>15 \mu \mathrm{g} / \mathrm{kg} / \mathrm{min}$ or epinephrine or

norepinephrine $>0.1 \mu \mathrm{g} / \mathrm{kg} / \mathrm{min}$

Creatinine $<1.2 \mathrm{mg} / \mathrm{dl}$

Creatinine $<2 \mathrm{mg} / \mathrm{dl}$

Creatinine $<3.5 \mathrm{mg} / \mathrm{dl}$

Creatinine $<5 \mathrm{mg} / \mathrm{dl}$

$\mathrm{UOP}<500 \mathrm{ml} / \mathrm{die}$

Creatinine $<1.2 \mathrm{mg} / \mathrm{dl}$

$\mathrm{UOP}<200 \mathrm{ml} /$ day

Platelet $>150.000 / \mu l$

Platelet $<150.000 / \mu$

Platelet $<100.000 / \mu$

Platelet $<50.000 / \mu 1$

Platelet $<20.000 / \mu 1$

GCS $\geq 15$
0

$2 \quad \mathrm{CPAP}>5 \mathrm{~cm} \mathrm{H}_{2} \mathrm{O}$ non invasively [171]

PEEP (invasively)

Administer fluids (at least $20 \mathrm{ml} / \mathrm{Kg}$ crystalloids in $30 \mathrm{~min}$ ) and monitor cardio-vascular and renal dysfunction.

1
2
3
4
0
1
2
3
4

$0 \quad$ Platelet transfusion in pts with DIC and bleeding (or a high risk of bleeding) with platelet $<50 / \mathrm{ml}[172]$ or $<20 / \mathrm{ml}$ [70]
If non-improving

$\mathrm{ICU}^{*}$

ICU

After $>4 \mathrm{~L}$, if there're is not improving ${ }^{\mathrm{b}}$ or if there is evidence of volume overload in ICU for vasopressor therapy

For the diagnosis and management of DIC see the guideline of BSCH [172] 


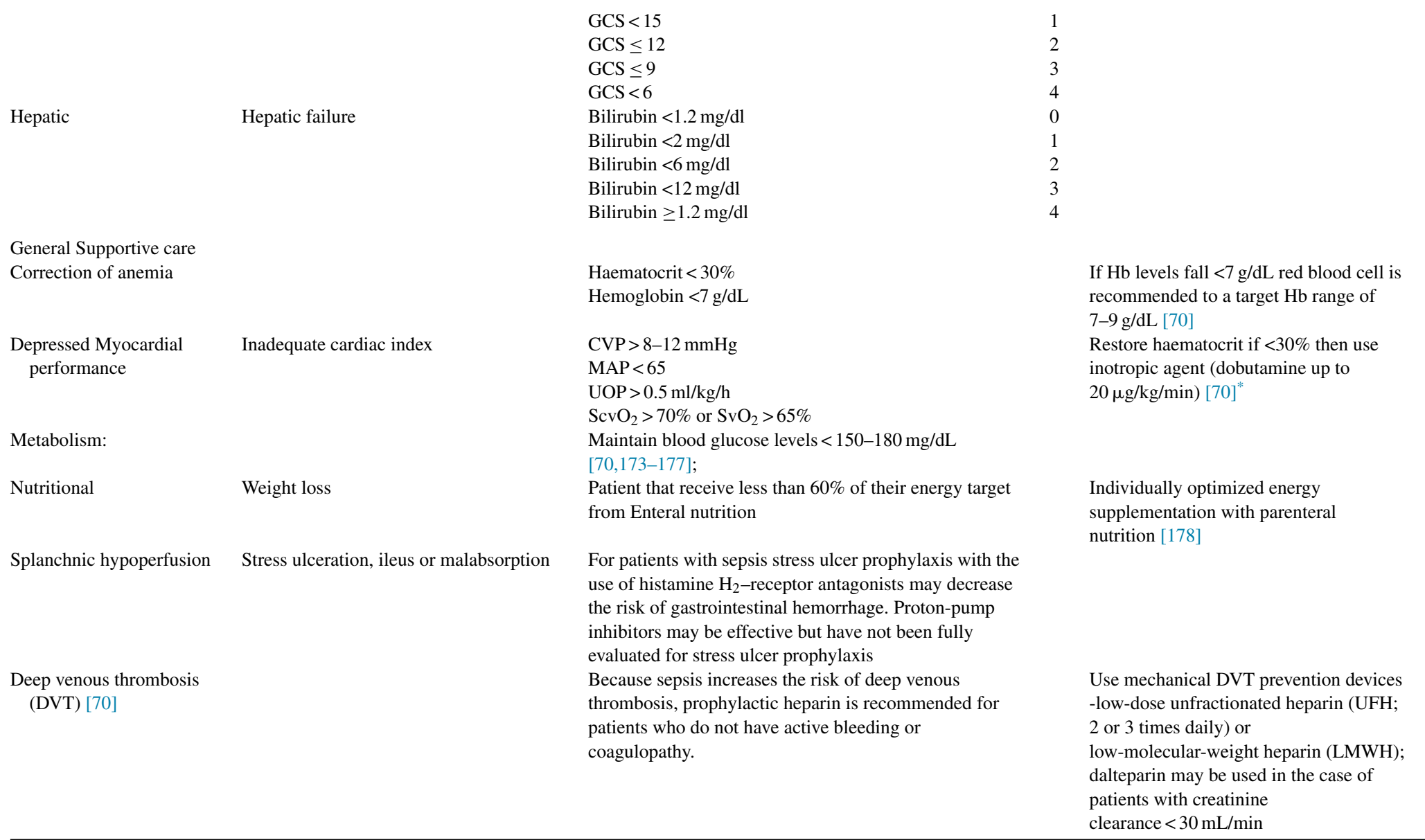

Acronyms: MODS: Multiorgan dysfunction; SOFA: Sequential Organ Failure Assessment; ALI: acute lung injury; ARDS acute respiratory distress syndrome; CPAP: Continuous Positive Airway Pressure; PEEP: Positive End Expiratory Pressure; MAP: Mean Arterial Pressure; UOP: Urine Output; DIC disseminated intravascular coagulation; BSCH: British Committee for Standards in Hematology; GCS: Glasgow Coma Scale; $\mathrm{SCvO}_{2}$ : Central Venous Oxygen Saturation; $\mathrm{SvO}_{2}$ : Mixed Venous Oxygen Saturation.

* Values or Treatment that, if not effective, indicate patient referal to the ICU.

a "VoL" clinical signs: dyspnea, elevated jugular pressure, crackles on auscultation, and pulmonary edema on chest Rx;

$\mathrm{b}$ improvement after fluid resuscitation of mental status, heart rate, MAP, capillary refill and UOP. 
for invasive procedures such as central venous cannulation, necessary for the measurement of central venous pressure and $\mathrm{SvO}_{2} / \mathrm{ScvO}_{2}$ [99-102]. Recent reports suggest that early lactate $[50,103,104]$ measurements might be equivalent to $\mathrm{SvO}_{2} / \mathrm{ScvO}_{2}$ monitoring in order to guide fluid resuscitation. Furthermore, lactate normalization has been shown to be noninferior to early resuscitation based on $\mathrm{ScvO}_{2}$ normalization $[50,105]$. Table 4 lists the parameters that need checking in order for organ dysfunctions to be monitored.

\subsection{Statements about hospitalization and antineoplastic treatment interruption}

\subsubsection{Hospitalization}

HNCPs with sepsis should be promptly hospitalized as this condition can progress rapidly.

\subsubsection{CT interruption}

For suspected or confirmed severe sepsis during CRT, CT should be the first treatment to be interrupted.

\subsubsection{RT interruption}

For suspected or confirmed sepsis during CRT, RT should be stopped only in particularly compromised patients or in the presence of severe sepsis.

Sepsis management requires multidisciplinary (oncologist/hematologist, IDP, CCP, nurses, pneumonologists, and dieticians), diagnostic and management actions that need to interact rapidly in order to maximize the chances of success [70]. Thus, the panel suggests that HNCPs undergoing CRT should be hospitalized when diagnostic criteria for sepsis [23] are associated with a suspected infection. This is so that HNCPs can progress more rapidly and that the specific antineoplastic treatments can continue safely by limiting interruption as much as possible.

In addition, the presence of sepsis should induce the interruption of $\mathrm{CT}$ administration, given its potential in worsening organ damage and in hindering immune responses. CT should be resumed when every organ failure is resolved and no sign of SIRS is present. Conversely, the radiotherapeutical systemic effects are less dangerous than chemotherapeutical ones: consequently, the panel suggests continuing RT as the advantage due to local-toxicity recovering could be annulled by the negative effects of tumor re-growth $[106,107]$. Of course, the symptoms of local toxicity must be monitored/controlled.

\subsection{Statements about the Early empirical antimicrobial treatment}

4.4.1 Empirical antibiotic therapy should be started within 3 h of clinical presentation

4.4.2 For suspected or confirmed sepsis (Systemic inflammatory response to infection; see Table 2) empirical antibiotic therapy should be started, considering both anti
Gram+ and anti Gram- antibiotics [108,109]. It should attempt to provide antimicrobial activity against the most likely pathogens based upon the potential source of infection searched on the basis of each HNCP's presenting illness

4.4.3 Empirical antibiotic therapy has to be based on local surveillance, antibiotic sensitivity and infection rate/prevalence; otherwise a rational use of antibiotics in accordance with international guidelines is advisable (e.g. Centers for Disease Control and Prevention CDC)

4.4.4 Considering the very high rate of infection sustained by multi-and pan-resistant microorganisms in the HNCPs as well as in the general population, when local guidelines are not available, it is suggested that treatment with broad spectrum, potent antibiotics active against enterobacteriaceae and methicillin-resistant Staphylococcus aureus be started

4.4.5 In the presence of sepsis following an oral cavity infection, the introduction of an antifungal agent associated with an anti-Gram+ antibiotic

4.4.6 Once aspiration pneumonia is suspected, a low threshold for CT scan and diagnostic bronchoscopy should be maintained

4.4.7 For healthcare-associated infections non-responsive to the first line of antibiotics, the IDPs' assessment is mandatory

Initiation of therapy may be necessary for unstable or high-risk patients while the diagnostic evaluation is ongoing [75]. If an infectious cause of fever is suspected, empirical antimicrobial therapy is urgent. Indeed, delaying effective antimicrobial therapy has been associated with increased mortality [49,110-114]. Barie and associates [115] demonstrated in a prospective observational study that the delayed-antibiotic therapy increased the risk of death by $2.1 \%$ for every 30 minutes' delay (OR, 1.021; 95\% CI, 1.003 to 1.038). Moreover, MacArthur et al. in a randomized trial obtained a $10 \%$ decrease in the overall crude-mortality with an adequate and early empirical antibiotic treatment [116]. Thus, antibiotics should be given before obtaining the results of cultures in any case suspected of having an infection and when one or more organ failures are manifested without other signs of infection.

The initial selection of antimicrobial therapy should be broad enough to cover all likely pathogens [110-112,115,117,118]. Kollef et al. showed [117] that the prior administration of antibiotics (implying an increased risk of resistant pathogens) and the presence of a bloodstream infection (especially catheter-related: implying resistant gram positive cocci and failure to treat fungemia empirically) were the main causes of inappropriate therapy and increased mortality.

Initial empirical anti-infective therapy includes one or more drugs that have activity against all likely pathogens (considering both Gram+ and Gram- and/or fungal or viral) and that penetrate in adequate concentrations into the tissues presumed to be the source of sepsis [70] (Table 5).

Thus, the main aims that should guide the choice of antiinfective treatments are $[69,70]$ : 
Table 5

Proposals from the literature of empiric antibiotic antimicrobial choice based on suspected site of infection.

\begin{tabular}{|c|c|c|}
\hline $\begin{array}{l}\text { Presume Site of the } \\
\text { source of infection }\end{array}$ & Local infection or critical colonization & Sepsis $^{a},{ }^{b}$ \\
\hline Pneumonia $^{c}$ & $\begin{array}{l}\text { Early onset, low risk for multi-drug resistant } \\
\text { organisms: } \\
\text { Out-patient: ceftriaxone plus azithromycin } \\
500 \mathrm{mg} \text { qd or levofloxacin } 500 \mathrm{mg} \text { bid or } \\
\text { moxifloxacin po } 400 \mathrm{mg} \text { qd } \\
\text { In-patient (IV) ampicillin/sulbactam } 3 \mathrm{~g} \\
\text { q8 } \mathrm{h},(\mathrm{IV}) \text { ceftriaxone plus (IV) azithromycin } \\
500 \mathrm{mg} \text { qd or levofloxacin } 750 \mathrm{mg} \text { qd or } \\
\text { moxifloxacin } 400 \mathrm{mg} \text { qd(IV) }\end{array}$ & $\begin{array}{l}\text { Late onset and/or risk factors for MDR organisms: } \\
\text { Meropenem (IV) } 1 \mathrm{~g} \mathrm{q} 8 \mathrm{~h} \text { or } \\
\text { Piperacillin/tazobactam (IV) } 4.5 \mathrm{~g} \mathrm{q} 6 \mathrm{~h} \text { or } \\
\text { Imipenem/cilastatin (IV) } 500 \mathrm{mg} \mathrm{q} 6 \mathrm{~h}(1 \mathrm{~g} \mathrm{q} 6-8 \mathrm{~h} \text { if } P \text {. aeruginosa is } \\
\text { suspected) } \\
P L U S \\
\text { Vancomycin (IV) } 15-20 \mathrm{mg} / \mathrm{kg} / \mathrm{dose} \mathrm{q} 8-12 \mathrm{~h} \text {, or } \\
\text { Linezolid } 600 \mathrm{mg} \text { (IV) } 12 \mathrm{~h}\end{array}$ \\
\hline Oral cavity & $\begin{array}{l}\text { Topical forms of fluconazole, Itraconazole, } \\
\text { nystatin suspension intra-orally [179]. }\end{array}$ & $\begin{array}{l}\text { Ampicillin/sulbactam } 3 \mathrm{~g} \mathrm{q} 8 \mathrm{~h} \text {, (IV) } \\
\text { PLUS } \\
\text { If suspected mycosis: } \\
\text { Fluconazole } 100 \mathrm{mg} \mathrm{q} 12 \mathrm{~h} \text { or Itraconazole oral solution } 100 \mathrm{mg} \\
\mathrm{q} 12 \mathrm{~h}[180] \\
\text { or } \\
\text { Echinocandins (anidulafungin, caspofungin and micafugnin) or } \\
\text { liposomal amphotericin B only in very severe and refractory cases } \\
\text { [181] }\end{array}$ \\
\hline
\end{tabular}

Central venous device [138]

Gastrostomy/Tracheostomy

Gastrointestinal Oesophageal

Diarrhea (consider C. difficile infection)
Early catheter removal (if possible)

Daptomycin $6 \mathrm{mg} / \mathrm{kg} / \mathrm{dose}$ IV once daily (in absence of pneumonia), or

Vancomycin (IV) $15-20 \mathrm{mg} / \mathrm{kg} /$ dose (actual body weight) every $8-12 \mathrm{~h}$

PLUS

Piperacillin/tazobactam (IV) $4.5 \mathrm{~g}$ every $6 \mathrm{~h}$ or meropenem (IV) $1 \mathrm{~g} \mathrm{q} 8 \mathrm{~h}$ or imipenem/cilastatin (IV) $500 \mathrm{mg} \mathrm{q} 6 \mathrm{~h}$ (1 $\mathrm{g} \mathrm{q} 6-8 \mathrm{~h}$ if $P$. aeruginosa is suspected) Mupirocin 2\%, gentamycin, eritrocyn or clortetracyclin topical ointment q8 h [182]

Moxifloxacin $400 \mathrm{mg}$ intravenously (IV) qd followed by moxifloxacin $400 \mathrm{mg}$ orally (PO) qd [183,184]

or

Amoxicillin/clavulanate and ciprofloxacin plus metronidazole [185]

Oral Vancomicin $125 \mathrm{mg} \mathrm{q} 6 \mathrm{~h}$ for 10 days or Teicoplanin $200 \mathrm{mg}$ o12 h or Fidaxomicin $200 \mathrm{mg} \mathrm{q} 12 \mathrm{~h}$ for 10 days
Piperacillin/tazobactam (IV) $4.5 \mathrm{~g}$ every $6 \mathrm{~h}$ or carbapenem (meropenem (IV) $1 \mathrm{~g} \mathrm{q} 8 \mathrm{~h}$ or imipenem/cilastatin (IV) $500 \mathrm{mg} \mathrm{q} 6 \mathrm{~h}$ PLUS

Vancomycin (IV) $15-20 \mathrm{mg} / \mathrm{kg} /$ dose (actual body weight) every $8-12 \mathrm{~h}$, or

Linezolid $600 \mathrm{mg}$ (IV) $\mathrm{q} 12 \mathrm{~h}$ or

Daptomycin (IV) $4 \mathrm{mg} / \mathrm{kg} / \mathrm{dose}$ once daily, or

Telavancin (IV) $10 \mathrm{mg} / \mathrm{kg} /$ dose IV once daily.

PLUS

If suspected invasive candidiasis/candidaemia: Caspofungin of micafungin or liposomal amphotericin B or anidulafungin [181] In case of peritonitis:

Piperacillin/tazobactam (IV) $4,5 \mathrm{~g}$ q6 h or

Imipenem/cilastatin (IV) $2 \mathrm{~g}$ q8 $\mathrm{h}$ or

Meropenem (IV) $2 \mathrm{~g} \mathrm{q} 8 \mathrm{~h} 3$ or

Tigecycline [185]

PLUS

Echinocandins (anidulafungin, caspofungin and micafugnin) or liposomal amphotericin B only in very severe and refractory cases [181]

Oral Vancomicin $125-500 \mathrm{mg} q 6 \mathrm{~h}$ for 10 days or

Teicoplanin $200 \mathrm{mg}$ o1 $2 \mathrm{~h}$ or

Fidaxomicin $200 \mathrm{mg}$ q $12 \mathrm{~h}$ for 10 days

When oral treatment is not possible, parenteral metronidazole $500 \mathrm{mg}$ tid for 10 days combined with intracolonic or nasogastric administration of vancomycin. 
Table 5 (Continued)

\begin{tabular}{|c|c|c|}
\hline $\begin{array}{l}\text { Presume Site of the } \\
\text { source of infection }\end{array}$ & Local infection or critical colonization & Sepsis $^{\mathrm{a}}$, \\
\hline $\begin{array}{l}\text { Sepsis }[109,186] \text { without } \\
\text { an individuated site }\end{array}$ & $\begin{array}{l}\text { In the case of non-HAI-suspected infection } \\
\text { ampicillin/sulbactam } 3 \mathrm{~g} \mathrm{q} 8 \mathrm{~h} \text {, plus } \\
\text { levofloxacin } 500 \mathrm{mg} \mathrm{qd}\end{array}$ & $\begin{array}{l}\text { In patients with HAI } \\
\text { Daptomycin (IV) } 6 \mathrm{mg} / \mathrm{kg} / \mathrm{dose} \text { once daily in absence of } \\
\text { pneumonia, or } \\
\text { Teicoplanin (IV) } 12 \mathrm{mg} / \mathrm{kg} / \mathrm{die} \text { or } \\
\text { Vancomycin }^{\mathrm{d}} \text { (IV) } 15-20 \mathrm{mg} / \mathrm{kg} / \text { dose (actual body weight) every } \\
8-12 \mathrm{~h} \text { or } \\
\text { Linezolid (IV) } 600 \mathrm{mg} \mathrm{q} 12 \mathrm{~h} \text { in absence of bacteremia, PLUS } \\
\text { Piperacillin/tazobactam (IV) } 4.5 \mathrm{~g} \text { every } 6 \mathrm{~h} \text { or } \\
\text { Carbapenem } \\
\text { PLUS } \\
\text { If suspected mycosis: } \\
\text { Echinocandins (anidulafungin, caspofungin and micafugnin) or } \\
\text { liposomal amphotericin B [181] }\end{array}$ \\
\hline
\end{tabular}

a If the patient is "antibiotic experienced" an amynoglicoside rather than a quinolone or cephalosporin for gram- is advisable. In fact certain microorganisms, chiefly Enterobacteriaceae (e.g., E. coli and K. pneumoniae), contain a beta-lactamase enzyme that inactivates penicillins and cephalosporins (Extended Spectrum Beta-Lactamase producing bacteria (ESBL) Patients presenting with ESBL-associated risk factors (intra-abdominal), tigecycline is recommended [185].

${ }^{b}$ The combined antibiotic therapy should consider pathogens with antibiotic resistance (such as MRSA, Pseudomonas species, and gram-negative organisms with ESBL activity) increasing the likelihood that at least one drug may be effective against that strain [187,188].

${ }^{c}$ Typically require dual broad-spectrum antibiotics with overlapping coverage [189-192].

${ }^{d}$ In patients with a history of IV drug use, those with indwelling vascular catheters or devices, or those with recent hospitalizations an agent such as daptomycin (in absence of pneumonia) or vancomycin (IF mic $\leq 1$ ) or linezolid (in absence of bacteremia) should be adopted.

${ }^{\text {e }}$ Cephamycins (e.g., cefotetan) and carbapenems (e.g., imipenem, meropenem, and ertapenem) [193] remain effective against ESBL-producing organisms.

- The evaluation of risks for infection by multidrug-resistant pathogens.

HNCPs having been treated with CT during the previous 30 days should be considered immunocompromised [119-121] and at high risk of healthcare-associated infections.

\section{- The evaluation of the suspected infection source}

The main infection sources in HNCPs are the respiratory tract, the oral cavity, and medical devices such as central venous catheters (CVCs) [122], especially total implanted access ports [123], gastrostomy [124], and tracheostomy [47].

- Respiratory infection is the most frequent non-cancer cause of morbidity/death in HNCPs. Indeed, Soares [82] and Downey [125] reported that the main reasons for ICU admission for HNCPs were sepsis and acute respiratory failure. Other authors [126,127] showed that the most common causes of non-cancer-associated morbidities/death are respiratory diseases. Indeed, aspiration of colonized oropharyngeal contents into the lower respiratory tract can be due to HNCPs' swallowing dysfunction $[45,128]$. Thus, pneumonia in HNCPs should be considered and treated according to the health-care acquired pneumonia (HCAP) criteria due to the frequent involvement of multidrug resistance organisms [121].

- Regarding the oral cavity, a systematic review shows that clinical oral fungal infection/colonization rises respectively to $37.4 \% / 72 \%$ during RT and $38 \% / 74.5 \%$ during CT. Candida albicans $(46.2 \%)$ was the prevalent colonizing fungi followed by C. tropicalis (16.6\%) [129]. Furthermore, shifts in oral bacterial flora (mainly from streptococci toward coagulase-positive staphylococci) [130]) have been attributed to CT, xerostomia, antibiotic use and associated neutropenia [130-132].

- Regarding device-related infection, it must be considered that a colonized foreign body serves as a continuing source of infection by multiple mechanisms: it impairs local host defenses and many of the organisms have the capacity to form a biofilm on invasive devices and so create a continuing focus of infection. Coagulase-negative Staphylococci species, for example, create a biofilm and therefore are a common cause of vascular catheter-related infections [133]. The infection due to these external-internal devices may be localized to entrance-site and/or tunnel (or port-pocket in the case of port-a-cath CVC) and, when associated to SIRS, is the cause of device-associated "blood systemic infection" (BSI).

Cancer patients with implantable port systems experienced a median of 0.2 infections per 1000 catheter-days (range: 0-2.7 per 1000 catheter-days) [134] versus a risk that ranges from 1.4 to 2.2 infections per 1000 catheter-days for subcutaneous tunneled CVCs $[135,136]$. Nevertheless, this difference may be biased by the fact that patients who receive implantable subcutaneous ports usually receive much less intensive cancer therapy [137]. Thus, the optimal device to be used during CRT is hardly advisable and needs further prospective trials.

Recommendations for culturing and treatment of catheter-related BSI are addressed by the Infectious Diseases Society of America [138,139]. In addition, ASCO guidelines [137] recommend immediate catheter removal for BSIs caused by fungi and non-tuburculous mycobacteria (e.g., M. chelonei, M. fortuitum, M. mucogenicum, 
M. abscessus). Furthermore, BSIs caused by Bacillus species, C. jeikeium, S. aureus, P. aeruginosa, S. maltophilia, and vancomycin-resistant enterococci may be difficult to eradicate with antimicrobial therapy alone, and early catheter removal should be considered. Finally, catheter removal should also be considered when blood cultures remain positive $48 \mathrm{~h}$ after the start of antibiotic treatment if no other infection site has been identified or if bacteremia recurs shortly after the completion of a course of antibiotics.

- Regarding the enteral nutrition, there were significantly more infections in the PEG group (66\%) compared to the NGT group (30\%) $p=0.001$ in the prospective study of Corry et al. [124], but the difference of pneumonia between the two groups ( $\mathrm{PEG}=31.3 \%$ vs. NGT $=30 \%$ ) was statistically insignificant. In fact, the majority of infections in the PEG group were at the PEG site (31\%: 10/32).

- Evaluation of antimicrobial sensitivity of local germ populations.

The prevalence of microorganisms differs according to the environments. Some authors [140] have observed that gram-positive bacteria prevail over the gram-negative ones as infectious pathogen in developed countries, probably because of the routine use of prophylactic oral antibiotics (such as quinolones, which can also favor bacteriaceae) [141] and the use of CVC [140]. Conversely gram-negative prevails in developing countries [142].

Consequently, most scientific guidelines $[70,120]$ recommend recognizing the variability of bacteriology from one hospital to another over time in order to select the most appropriate antibiotic regimen.

\subsection{Statement about the antibiotic de-escalation procedure}

\subsubsection{The empirical treatment must be optimized when microbiology results are available}

The empirical combination antimicrobial therapy should not be administered for longer than 3-5 days [70]. After that period, treatment de-escalation to the most appropriate single-agent therapy should be performed as soon as the susceptibility profile is known [109]. This should minimize the risk of inducing toxicity and bacterial resistance, and of developing superinfections with other resistant organisms such as Candida species, Clostridium difficile or vancomycin-resistant Enterococcus faecium. Concern about under treatment due to de-escalation is unfounded [143]. The "Surviving sepsis campaign" [70] suggests the duration of therapy be 7-10 days if clinically indicated; longer courses may be appropriate in patients who have a slow clinical response, undrainable foci of infection, bacteremia with MRSA; some fungal and viral infections, or immunological deficiencies, including neutropenia.

The use of procalcitonin $[64,144,145]$ or similar biomarkers may facilitate discontinuance of antibiotics in a patient with clinical improvement, although one recent study failed to show any benefit of daily procalcitonin measurement [146].

\subsection{Statements about early goal-directed treatment (EGDT)}

4.6.1 In cases of severe sepsis (sepsis \pm organ failure) supportive therapy using the "EGDT" scheme should be applied as soon as possible: oxygen administration, hydration with crystalloids, and targeting a Svo 2 of $70 \%$

4.6.2 Most patients with severe sepsis (see Table 4) should be rapidly referred to an intensive care unit (ICU)

In 2004, the "Surviving Sepsis Campaign" guidelines recommended the use of EGDT [147] based on one large randomized trial [93]. These guidelines were updated in 2008 [148], successively in 2012 [70], and were further supported by several subsequent trials that corroborated the benefit of EGDT in severe sepsis and septic shock [149].

Rivers [93] showed there was an increase in survival at 28 days through EGDT application in a randomized study in which patients with severe sepsis and septic shock received EGDT during the first $6 \mathrm{~h}$ after enrolment or the usual therapy. EGDT involves identifitcation of high-risk patients (see Table 4), invasive monitoring, and 6 hours of protocolled resuscitation with fluids, vasoactive agents, and packed red blood cells. Although these strategies are common in the ICU, they are not in oncology or internal medicine wards. Recently, some authors have not found any significant benefit of the mandated use of central venous catheterization and central hemodynamic monitoring in all patients [102].

The mechanisms of the benefit of EGDT are unknown but may include reversal of tissue hypoxia and a decrease in inflammation and coagulation defects.

\subsection{Statement about the follow up}

\subsubsection{Monitoring for SIRS parameters should be continued after the end of CRT until the complete resolution of acute toxicities. Indeed, mortality for pneumonia is reported to occur well after 30 days from the end of treatments and there is a high risk of infection for several months}

Mortality for pneumonia is reported to occur well beyond 30 days after the end of treatments and a high risk of infection is maintained for several months $[6,12]$. Indeed, it must be considered that the local damage and nutritional impairment last several months after the end of treatment [150], consequently the risk of infection remains higher well after the end of treatment.

\section{Conclusions}

The sepsis in CRT-treated HNCPs is a serious much-feared complication and constitutes a reason for treatment reduction, delay, or interruption. It may affect the prognosis and 
cause the death of potentially curable patients. In order to better manage this adverse event, it is necessary to standardize clinical definitions, diagnosis, management, and treatment according to international guidelines. Since very little has been written concerning severe sepsis in HNCPs, our review aimed to obtain some indications for the management of septic patients from literature and tried to draw up recommendations/suggestions for HNCPs, based on the consensus among multidisciplinary health professionals. The main aim is to standardize their diagnostic and treatment behavior.

Obviously, the main limit of this study is the fact that most literature is obtained from non-HNCPs.

\section{Funding}

This study was partly supported ( $400.00 €$ for the mothertongue assistance in English) by Lega Tumori sezione di Cuneo via Meucci 12100 Cuneo. Italy.

\section{Conflict of interest statement}

The Authors have no financial and personal relationships with other people or organizations that could inappropriately influence (bias) this work.

\section{Reviewers}

René-Jean Bensadoun, Chairman PRC, CHU de Poitiers, Radiation Oncology Department, 2 rie de la Milétrie, BP 577, F-86021 Poitiers Cedex, France.

Jean Klastersky, Ph.D., Institut Jules Bordet, Department of Medicine, 121 Boulevard de Waterloolaan, B-1000 Brussels, Belgium.

\section{Acknowledgments}

Airoldi Mario (Turin), Alterio Daniela (Milan), Azzarello Giuseppe (Padova), Bolner Andrea (Trento), Cerrina Olivia (Cuneo), Corvò Renzo (Genova), Fiscella Michela (Milan), Gavazzi Cecilia (Nutritionist), Grisanti Salvatore (Brescia), Magrini Stefano (Brescia), Maurizi Enrici Riccardo (Rome), Orlandi Ester (Milano), Paganelli Corrado (Brescia), Paiar Fabiola (Firenze), Pavanato Giovanni (Rovigo), Pinto Carmine (Bologna), Pizzorni Nicole (Milano), Rampino Monica (Turin), Ripamonti Carla (Milan), Salgarello Stefano (Brescia), Giuseppe Sanguineti (Rome).

\section{References}

[1] Pignon J-P, Le Maître A, Maillard E, Bourhis J. Meta-analysis of chemotherapy in head and neck cancer (MACH-NC): An update on 93 randomised trials and 17,346 patients. Radiother Oncol 2009;92:4-14, http://dx.doi.org/10.1016/j.radonc.2009.04.014.
[2] Forastiere AA, Zhang Q, Weber RS, et al. Long-term results of RTOG 91-11: a comparison of three nonsurgical treatment strategies to preserve the larynx in patients with locally advanced larynx cancer. J Clin Oncol 2013;31:845-52, http://dx.doi.org/10.1200/JCO.2012.43.6097.

[3] Mell LK, Dignam JJ, Salama JK, et al. Predictors of competing mortality in advanced head and neck cancer. J Clin Oncol Off J Am Soc Clin Oncol 2010;28:15-20, http://dx.doi.org/10.1200/JCO.2008.20.9288.

[4] Russi EG, Numico G, Merlano MC. Nonsurgical conservative approach for laryngeal cancer: what information should patients be given? J Clin Oncol Off J Am Soc Clin Oncol 2013;31:3168-70, http://dx.doi.org/10.1200/JCO.2013.49.9491.

[5] Brizel DM, Albers ME, Fisher SR, et al. Hyperfractionated irradiation with or without concurrent chemotherapy for locally advanced head and neck cancer. N Engl J Med 1998;338:1798-804, http://dx.doi.org/10.1056/NEJM199806183382503.

[6] Argiris A, Brockstein BE, Haraf DJ, et al. Competing causes of death and second primary tumors in patients with locoregionally advanced head and neck cancer treated with chemoradiotherapy. Clin Cancer Res 2004;10:1956-62, http://dx.doi.org/10.1158/1078-0432.CCR-03-1077.

[7] Chang P-H, Yeh K-Y, Huang J-S, et al. Pretreatment performance status and nutrition are associated with early mortality of locally advanced head and neck cancer patients undergoing concurrent chemoradiation. Eur Arch Otorhinolaryngol 2013;270:1909-15, http://dx.doi.org/10.1007/s00405-012-2290-2.

[8] Sonis S, Haddad R, Posner M, et al. Gene expression changes in peripheral blood cells provide insight into the biological mechanisms associated with regimen-related toxicities in patients being treated for head and neck cancers. Oral Oncol 2007;43:289-300, http://dx.doi.org/10.1016/j.oraloncology.2006.03.014.

[9] Logan R, Stringer A, Bowen J, Gibson R, Sonis ST, Keefe DMK. Serum levels of NF- $\kappa B$ and pro-inflammatory cytokines following administration of mucotoxic drugs. Cancer Biol Ther 2008;7:1139-45, http://dx.doi.org/10.4161/cbt.7.7.6207.

[10] Siva S, Macmanus MP, Martin RF, Martin OA. Abscopal effects of radiation therapy: a clinical review for the radiobiologist. Cancer Lett 2013, http://dx.doi.org/10.1016/j.canlet.2013.09.018.

[11] Numico G, Russi EG, Vitiello R, et al. Gemcitabine and cisplatin in a concomitant alternating chemoradiotherapy program for locally advanced head-and-neck cancer: a pharmacology-guided schedule. Int J Radiat Oncol 2006;66:731-7, http://dx.doi.org/10.1016/j.ijrobp.2006.05.059.

[12] Lee C-C, Ho H-C, Hsiao S-H, et al. Infectious complications in head and neck cancer patients treated with cetuximab: propensity score and instrumental variable analysis. PLoS ONE 2012;7:e50163, http://dx.doi.org/10.1371/journal.pone.0050163.

[13] Bone RC, Fisher Jr CJ, Clemmer TP, Slotman GJ, Metz CA, Balk RA. Sepsis syndrome: a valid clinical entity. Methylprednisolone Severe Sepsis Study Group. Crit Care Med 1989;17:389-93.

[14] Bone RC, Balk RA, Cerra FB, et al. Definitions for sepsis and organ failure and guidelines for the use of innovative therapies in sepsis. the accp/sccm consensus conference committee. American college of chest physicians/society of critical care medicine. Chest J 1992;101:1644-55, http://dx.doi.org/10.1378/chest.101.6.1644.

[15] Vincent J-L. Definition of sepsis and non-infectious SIRS. Sepsis non-infect. syst. inflamm. John Wiley \& Sons; 2008. p. 312.

[16] Vincent J-L, Martinez EO, Silva E. Evolving concepts in sepsis definitions. Crit Care Clin 2009;25:665-75, http://dx.doi.org/10.1016/j.ccc.2009.07.001.

[17] Bone RC. Sepsis, the sepsis syndrome, multi-organ failure: a plea for comparable definitions. Ann Intern Med 1991;114:332-3, http://dx.doi.org/10.7326/0003-4819-114-4-332.

[18] Loblaw DA, Prestrud AA, Somerfield MR, et al. American society of clinical oncology clinical practice guidelines: formal systematic review-based consensus methodology. J Clin Oncol 2012;30:3136-40, http://dx.doi.org/10.1200/JCO.2012.42.0489. 
[19] Cerra FB. The systemic septic response: multiple systems organ failure. Crit Care Clin 1985;1:591-607.

[20] Russi EG, Raber-Durlacher JE, Sonis ST. Local and systemic pathogenesis and consequences of regimen-induced inflammatory responses in patients with head and neck cancer receiving chemoradiation. Mediators Inflamm 2014;2014:518261, http://dx.doi.org/10.1155/2014/518261.

[21] Marshall J. Both the disposition and the means of cure: "severe SIRS," "sterile shock", and the ongoing challenge of description. Crit Care Med 1997;25:1765-6.

[22] Vincent JL, Dear SIRS. I'm sorry to say that I don't like you. Crit Care Med 1997;25:372-4.

[23] Levy MM, Fink MP, Marshall JC, et al. 2001 SCCM/ESICM/ACCP/ATS/SIS international sepsis definitions conference. Intensive Care Med 2003;29:530-8, http://dx.doi.org/10.1007/s00134-003-1662-x.

[24] Cascio A, Iaria C. Sepsis definitions. Lancet 2013;381:2249, http://dx.doi.org/10.1016/S0140-6736(13)61473-7.

[25] Vincent J-L, Opal SM, Marshall JC, Tracey KJ. Sepsis definitions: time for change. Lancet 2013;381:774-5, http://dx.doi.org/10.1016/S0140-6736(12)61815-7.

[26] Janeway CA, Medzhitov R. Innate immune recognition. Annu Rev Immunol 2002;20:197-216, http://dx.doi.org/10.1146/annurev.immunol.20.083001.084359.

[27] Matzinger P. The danger model: a renewed sense of self. Science 2002;296:301-5, http://dx.doi.org/10.1126/science.1071059.

[28] Oppenheim JJ, Yang D. Alarmins: chemotactic activators of immune responses. Curr Opin Immunol 2005;17:359-65, http://dx.doi.org/10.1016/j.coi.2005.06.002.

[29] Bianchi ME, DAMPs. PAMPs and alarmins: all we need to know about danger. J Leukoc Biol 2007;81:1-5, http://dx.doi.org/10.1189/jlb.0306164.

[30] Elting LS, Cooksley CD, Chambers MS, Garden AS. Risk, outcomes, and costs of radiation-induced oral mucositis among patients with head-and-neck malignancies. Int J Radiat Oncol Biol Phys 2007;68:1110-20, http://dx.doi.org/10.1016/j.ijrobp.2007.01.053.

[31] Zunt SL, Burton LV, Goldblatt LI, Dobbins EE, Srinivasan M. Soluble forms of Toll-like receptor 4 are present in human saliva and modulate tumour necrosis factor- $\alpha$ secretion by macrophage-like cells. Clin Exp Immunol 2009;156:285-93, http://dx.doi.org/10.1111/j.1365-2249.2009.03854.x.

[32] Bahri R, Saidane-Mosbahi D, Rouabhia M. Candida famata modulates toll-like receptor, $\beta$-defensin, and proinflammatory cytokine expression by normal human epithelial cells. J Cell Physiol 2010;222:209-18, http://dx.doi.org/10.1002/jcp.21939.

[33] Geijtenbeek TBH, Gringhuis SI. Signalling through C-type lectin receptors: shaping immune responses. Nat Rev Immunol 2009;9:465-79, http://dx.doi.org/10.1038/nri2569.

[34] Alexander C, Haylett R, Schromm A, Zahringer U, Rink L. Pathogens in sepsis: gram-positive bacterial pamps, prrs and superantigens. sepsis non-infect. syst. inflamm., vol. Chapter 6. John Wiley \& Sons; 2008. p. 109-44.

[35] Schromm A, Alexander C, Gutsmann T, Andr_-å J, Stamme C. Pathogens in sepsis: Gram-negative bacterial PAMPs and PRRs. sepsis non-infect. syst. inflamm., vol. Chapter 5. John Wiley \& Sons; 2008. p. 79-108.

[36] Pradeu T, Cooper EL. The danger theory: 20 years later. Front Inflamm 2012;3:287, http://dx.doi.org/10.3389/fimmu.2012.00287.

[37] Munford RS, Pugin J. Normal responses to injury prevent systemic inflammation and can be immunosuppressive. Am J Respir Crit Care Med 2001;163:316-21.

[38] Cavaillon J-M, Annane D. Invited review: compartmentalization of the inflammatory response in sepsis and SIRS. J Endotoxin Res 2006;12:151-70, http://dx.doi.org/10.1177/09680519060120030301.
[39] Cavaillon J-M. Septic Plasma: an immunosuppressive milieu. Am J Respir Crit Care Med 2002;166:1417-8, http://dx.doi.org/10.1164/rccm.2209003.

[40] Blijlevens NMA, Donnelly JP. Mucosal barrier injury and infections. princ. pract. cancer infect. dis. Totowa, NJ: Springer Science+Business Media, LLC; 2011. p. 167-73.

[41] Pinsky MR, Vincent JL, Deviere J, Alegre M, Kahn RJ, Dupont E. SErum cytokine levels in human septic shock. relation to multiplesystem organ failure and mortality. Chest J 1993;103:565-75, http://dx.doi.org/10.1378/chest.103.2.565.

[42] Vermont CL, Hazelzet JA, de Kleijn ED, van den Dobbelsteen GPJM, de Groot R. CC and CXC chemokine levels in children with meningococcal sepsis accurately predict mortality and disease severity. Crit Care Lond Engl 2006;10:R33, http://dx.doi.org/10.1186/cc4836.

[43] Hildebrand F, Stuhrmann M, van Griensven M, et al. Association of IL-8-251A/T polymorphism with incidence of Acute Respiratory Distress Syndrome (ARDS) and IL-8 synthesis after multiple trauma. Cytokine 2007;37:192-9, http://dx.doi.org/10.1016/j.cyto.2007.03.008.

[44] Van der Poll T, Opal SM. Host-pathogen interactions in sepsis. Lancet Infect Dis 2008;8:32-43, http://dx.doi.org/10.1016/S1473-3099(07)70265-7.

[45] Russi EG, Corvò R, Merlotti A, et al. Swallowing dysfunction in head and neck cancer patients treated by radiotherapy: review and recommendations of the supportive task group of the Italian Association of Radiation Oncology. Cancer Treat Rev 2012;38:1033-49, http://dx.doi.org/10.1016/j.ctrv.2012.04.002.

[46] Bagaitkar J, Demuth DR, Scott DA. Tobacco use increases susceptibility to bacterial infection. Tob Induc Dis 2008;4:12, http://dx.doi.org/10.1186/1617-9625-4-12.

[47] McMaster SK, Paul-Clark MJ, Walters M, et al. Cigarette smoke inhibits macrophage sensing of Gram-negative bacteria and lipopolysaccharide: relative roles of nicotine and oxidant stress. Br J Pharmacol 2008;153:536-43, http://dx.doi.org/10.1038/sj.bjp.0707595.

[48] Szabo G. Alcohol's contribution to compromised immunity. Alcohol Health Res World 1997;21:30-41

[49] Levy MM, Dellinger RP, Townsend SR, et al. The surviving sepsis campaign: results of an international guideline-based performance improvement program targeting severe sepsis. Crit Care Med 2010;38(February):367-74, http://dx.doi.org/10.1097/CCM.0b013e3181cb0cdc.

[50] Jones AE, Shapiro NI, Trzeciak S, et al. Lactate clearance vs central venous oxygen saturation as goals of early sepsis therapy: a randomized clinical trial. J Am Med Assoc 2010;303:739-46, http://dx.doi.org/10.1001/jama.2010.158.

[51] Bota DP, Melot C, Ferreira FL, Vincent J-L. Infection Probability Score (IPS): A method to help assess the probability of infection in critically ill patients. Crit Care Med 2003;31(November):2579-84.

[52] Martini A, Gottin L, Mélot C, Vincent JL. A prospective evaluation of the Infection Probability Score (IPS) in the intensive care unit. J Infect 2008;56:313-8, http://dx.doi.org/10.1016/j.jinf.2008.02.015.

[53] Simon L, Gauvin F, Amre DK, Saint-Louis P, Lacroix J. Serum procalcitonin and C-reactive protein levels as markers of bacterial infection: a systematic review and meta-analysis. Clin Infect Dis 2004;39:206-17, http://dx.doi.org/10.1086/421997.

[54] Uzzan B, Cohen R, Nicolas P, Cucherat M, Perret GY. Procalcitonin as a diagnostic test for sepsis in critically ill adults and after surgery or trauma: a systematic review and meta-analysis. Crit Care Med 2006;34:1996-2003, http://dx.doi.org/10.1097/01.CCM.0000226413.54364.36.

[55] Jones AE, Fiechtl JF, Brown MD, Ballew JJ, Kline JA. Procalcitonin test in the diagnosis of bacteremia: a meta-analysis. Ann Emerg Med 2007;50:34-41, http://dx.doi.org/10.1016/j.annemergmed.2006.10.020. 
[56] Lipsett sepsis- source unknown: how should one work up and manage the patient? Sepsis non-infect. syst. inflamm. John Wiley \& Sons; 2008. p. 157-63.

[57] Sanders S, Barnett A, Correa-Velez I, Coulthard M, Doust J. Systematic review of the diagnostic accuracy of C-reactive protein to detect bacterial infection in nonhospitalized infants and children with fever. J Pediatr 2008;153, http://dx.doi.org/10.1016/j.jpeds.2008.04.023, 570-4.e3.

[58] Wacker C, Prkno A, Brunkhorst FM, Schlattmann P. Procalcitonin as a diagnostic marker for sepsis: a systematic review and meta-analysis. Lancet Infect Dis 2013;13:426-35, http://dx.doi.org/10.1016/S1473-3099(12)70323-7.

[59] Miller PR, Munn DD, Meredith JW, Chang MC. Systemic inflammatory response syndrome in the trauma intensive care unit: who is infected? J Trauma 1999;47:1004-8.

[60] Assicot M, Bohuon C, Gendrel D, Raymond J, Carsin H, Guilbaud J. High serum procalcitonin concentrations in patients with sepsis and infection. Lancet 1993;341:515-8, http://dx.doi.org/10.1016/0140-6736(93)90277-N.

[61] Al-Nawas B, Shah PM. Procalcitonin, a new diagnostic and prognostic marker for severe infections. Clin Microbiol Infect Off Publ Eur Soc Clin Microbiol Infect Dis 1998;4:237-41.

[62] Brunkhorst FM, Wegscheider K, Forycki ZF, Brunkhorst R. Procalcitonin for early diagnosis and differentiation of SIRS, sepsis, severe sepsis, and septic shock. Intensive Care Med 2000;26(Suppl. 2):S148-52, http://dx.doi.org/10.1007/BF02900728.

[63] Loonen AJM, de Jager CPC, Tosserams J, et al. Biomarkers and molecular analysis to improve bloodstream infection diagnostics in an emergency care unit. PLoS ONE 2014;9:e87315, http://dx.doi.org/10.1371/journal.pone.0087315.

[64] Hohn A, Schroeder S, Gehrt A, et al. Procalcitonin-guided algorithm to reduce length of antibiotic therapy in patients with severe sepsis and septic shock. BMC Infect Dis 2013;13:158, http://dx.doi.org/10.1186/1471-2334-13-158.

[65] Ugarte H, Silva E, Mercan D, De Mendonca A, Vincent J-L. Procalcitonin used as a marker of infection in the intensive care unit. Crit Care Med 1999;27(March):498-504.

[66] Giamarellos-Bourboulis EJ, Giannopoulou P, Grecka P, Voros D, Mandragos K, Giamarellou H. Should procalcitonin be introduced in the diagnostic criteria for the systemic inflammatory response syndrome and sepsis? J Crit Care 2004;19:152-7, http://dx.doi.org/10.1016/j.jcrc.2004.07.001.

[67] Christ-Crain M, Stolz D, Bingisser R, et al. Procalcitonin guidance of antibiotic therapy in community-acquired pneumonia: a randomized trial. Am J Respir Crit Care Med 2006;174:84-93, http://dx.doi.org/10.1164/rccm.200512-1922OC.

[68] Stolz D, Christ-Crain M, Bingisser R, et al. Antibiotic treatment of exacerbations of COPD: a randomized, controlled trial comparing procalcitonin-guidance with standard therapy. Chest 2007;131:9-19, http://dx.doi.org/10.1378/chest.06-1500.

[69] O’Grady NP, Barie PS, Bartlett JG, et al. Guidelines for evaluation of new fever in critically ill adult patients: 2008 update from the American College of Critical Care Medicine and the Infectious Diseases Society of America. Crit Care Med 2008;36:1330-49, http://dx.doi.org/10.1097/CCM.0b013e318169eda9.

[70] Dellinger RP, Levy MM, Rhodes A, et al. Surviving sepsis campaign: international guidelines for management of severe sepsis and septic shock, 2012. Intensive Care Med 2013;39:165-228, http://dx.doi.org/10.1007/s00134-012-2769-8.

[71] Vincent J-L, Sakr Y, Sprung CL, et al. Sepsis in European intensive care units: results of the SOAP study. Crit Care Med 2006;34: 344-53.

[72] Weinstein MP, Reller LB, Murphy JR, Lichtenstein KA. The clinical significance of positive blood cultures: a comprehensive analysis of 500 episodes of bacteremia and fungemia in adults. I. Laboratory and epidemiologic observations. Rev Infect Dis 1983;5:35-53.
[73] Blot F, Schmidt E, Nitenberg G, et al. Earlier positivity of centralvenous- versus peripheral-blood cultures is highly predictive of catheter-related sepsis. J Clin Microbiol 1998;36:105-9.

[74] Seifert H, Cornely O, Seggewiss K, et al. Bloodstream infection in neutropenic cancer patients related to short-term nontunnelled catheters determined by quantitative blood cultures, differential time to positivity, and molecular epidemiological typing with pulsed-field gel electrophoresis. J Clin Microbiol 2003;41:118-23, http://dx.doi.org/10.1128/JCM.41.1.118-123.2003.

[75] Aarts M-AW, Granton J, Cook DJ, Bohnen JMA, Marshall JC. Empiric antimicrobial therapy in critical illness: results of a surgical infection society survey. Surg Infect 2007;8:329-36, http://dx.doi.org/10.1089/sur.2006.072.

[76] Sendid B, Jouault T, Coudriau R, et al. Increased sensitivity of mannanemia detection tests by joint detection of $\alpha$ - and $\beta$-linked oligomannosides during experimental and human systemic candidiasis. J Clin Microbiol 2004;42:164-71, http://dx.doi.org/10.1128/JCM.42.1.164-171.2004.

[77] Mourad O, Palda V, Detsky AS. A comprehensive evidencebased approach to fever of unknown origin. Arch Intern Med 2003;163:545-51, http://dx.doi.org/10.1001/archinte.163.5.545.

[78] Gaeta GB, Fusco FM, Nardiello S. Fever of unknown origin: a systematic review of the literature for 1995-2004. Nucl Med Commun 2006;27:205-11.

[79] Bleeker-Rovers CP, Vos FJ, van der Graaf WTA, Oyen WJG. Nuclear medicine imaging of infection in cancer patients (with emphasis on FDG-PET). Oncologist 2011;16:980-91, http://dx.doi.org/10.1634/theoncologist.2010-0421.

[80] Brun-Buisson C, Doyon F, Carlet J, et al. Incidence, risk factors, and outcome of severe sepsis and septic shock in adults: a multicenter prospective study in intensive care units. J Am Med Assoc 1995;274:968-74, http://dx.doi.org/10.1001/jama.1995.03530120060042.

[81] Russell JA. Management of sepsis. NEngl J Med 2006;355:1699-713, http://dx.doi.org/10.1056/NEJMra043632.

[82] Soares M, Salluh J, Toscano L, Dias F. Outcomes and prognostic factors in patients with head and neck cancer and severe acute illnesses. Intensive Care Med 2007;33:2009-13, http://dx.doi.org/10.1007/s00134-007-0775-z.

[83] Elbers PWG, Ince C. Mechanisms of critical illness - classifying microcirculatory flow abnormalities in distributive shock. Crit Care Lond Engl 2006;10:221, http://dx.doi.org/10.1186/cc4969.

[84] Marshall JC. Inflammation, coagulopathy, and the pathogenesis of multiple organ dysfunction syndrome. Crit Care Med 2001;29:S99-106

[85] Crouser ED. Mitochondrial dysfunction in septic shock and multiple organ dysfunction syndrome. Mitochondrion 2004;4:729-41, http://dx.doi.org/10.1016/j.mito.2004.07.023.

[86] Neligan PJ, Fanning N. What is the best way to fluid-resuscitate a patient with sepsis? Evid-based pract. crit. care. Philadelphia, PA: Saunders/Elsevier; 2010. p. 198-226.

[87] Finkel MS, Oddis CV, Jacob TD, Watkins SC, Hattler BG, Simmons RL. Negative inotropic effects of cytokines on the heart mediated by nitric oxide. Science 1992;257:387-9.

[88] Court O, Kumar A, Parrillo JE, Kumar A. Clinical review: myocardial depression in sepsis and septic shock. Crit Care Lond Engl 2002;6:500-8

[89] Cortez A, Zito J, Lucas CE, Gerrick SJ. MEchanism of inappropriate polyuria in septic patients. Arch Surg 1977;112:471-6, http://dx.doi.org/10.1001/archsurg.1977.01370040123019.

[90] Rady MY, Rivers EP, Nowak RM. Resuscitation of the critically ill in the ED: responses of blood pressure, heart rate, shock index, central venous oxygen saturation, and lactate. Am J Emerg Med $1996 ; 14: 218-25$.

[91] Wo CC, Shoemaker WC, Appel PL, Bishop MH, Kram HB, Hardin E. Unreliability of blood pressure and heart rate to evaluate cardiac 
output in emergency resuscitation and critical illness. Crit Care Med $1993 ; 21: 218-23$.

[92] Meregalli A, Oliveira RP, Friedman G. Occult hypoperfusion is associated with increased mortality in hemodynamically stable, high-risk, surgical patients. Crit Care 2004;8:R60.

[93] Rivers E, Nguyen B, Havstad S, et al. Early goal-directed therapy in the treatment of severe sepsis and septic shock. N Engl J Med 2001;345:1368-77, http://dx.doi.org/10.1056/NEJMoa010307.

[94] Schulman AM, Claridge JA, Carr G, Diesen DL, Young JS. Predictors of patients who will develop prolonged occult hypoperfusion following blunt trauma. J Trauma Inj Infect Crit Care 2004;57:795-800, http://dx.doi.org/10.1097/01.TA.0000140835.65944.54.

[95] Shapiro NI, Howell MD, Talmor D, et al. Serum lactate as a predictor of mortality in emergency department patients with infection. Ann Emerg Med 2005;45:524-8, http://dx.doi.org/10.1016/j.annemergmed.2004.12.006.

[96] Howell MD, Donnino M, Clardy P, Talmor D, Shapiro NI. Occult hypoperfusion and mortality in patients with suspected infection. Intensive Care Med 2007;33:1892-9, http://dx.doi.org/10.1007/s00134-007-0680-5.

[97] Mikkelsen ME, Miltiades AN, Gaieski DF, et al. Serum lactate is associated with mortality in severe sepsis independent of organ failure and shock. Crit Care Med 2009;37(May):1670-7, http://dx.doi.org/10.1097/CCM.0b013e31819fcf68.

[98] Elliott DC. An evaluation of the end points of resuscitation. J Am Coll Surg 1998;187:536-47, http://dx.doi.org/10.1016/S1072-7515(98)00232-4.

[99] De Miguel-Yanes JM, Andueza-Lillo JA, González-Ramallo VJ, Pastor L, Muñoz J. Failure to implement evidence-based clinical guidelines for sepsis at the ED. Am J Emerg Med 2006;24:553-9, http://dx.doi.org/10.1016/j.ajem.2006.01.012.

[100] Casserly B, Baram M, Walsh P, Sucov A, Ward NS, Levy MM. Implementing a collaborative protocol in a sepsis intervention program: lessons learned. Lung 2011;189:11-9, http://dx.doi.org/10.1007/s00408-010-9266-z.

[101] Cronshaw HL, Daniels R, Bleetman A, Joynes E, Sheils M. Impact of the surviving sepsis campaign on the recognition and management of severe sepsis in the emergency department: are we failing? Emerg Med J 2011;28:670-5, http://dx.doi.org/10.1136/emj.2009.089581.

[102] ProCESS Investigators, Yealy DM, Kellum JA, et al. A randomized trial of protocol-based care for early septic shock. N Engl J Med 2014;370:1683-93, http://dx.doi.org/10.1056/NEJMoa1401602.

[103] Mato AR, Luger SM, Heitjan DF, et al. Elevation in serum lactate at the time of Febrile Neutropenia (FN) in hemodynamically-stable patients with Hematologic Malignancies (HM) is associated with the development of septic shock within 48 hours. Cancer Biol Ther 2010;9:585-9, http://dx.doi.org/10.4161/cbt.9.8.11270.

[104] Hanzelka KM, Yeung S-CJ, Chisholm G, et al. Implementation of modified early-goal directed therapy for sepsis in the emergency center of a comprehensive cancer center. Support Care Cancer 2013;21:727-34, http://dx.doi.org/10.1007/s00520-012-1572-y.

[105] Jansen TC, van Bommel J, Schoonderbeek FJ, et al. Early lactateguided therapy in intensive care unit patients: a multicenter, open-label, randomized controlled trial. Am J Respir Crit Care Med 2010;182:752-61, http://dx.doi.org/10.1164/rccm.200912-1918OC.

[106] Robertson C, Robertson AG, Hendry JH, et al. Similar decreases in local tumor control are calculated for treatment protraction and for interruptions in the radiotherapy of carcinoma of the larynx in four centers. Int J Radiat Oncol 1998;40:319-29, http://dx.doi.org/10.1016/S0360-3016(97)00716-5.

[107] Rades D, Stoehr M, Kazic N, et al. Locally advanced stage iv squamous cell carcinoma of the head and neck: impact of pre-radiotherapy hemoglobin level and interruptions during radiotherapy. Int J Radiat Oncol 2008;70:1108-14, http://dx.doi.org/10.1016/j.ijrobp.2007.07.2380.

[108] Liu C, Bayer A, Cosgrove SE, et al. Clinical Practice Guidelines by the Infectious Diseases Society of America for the Treatment of Methicillin-Resistant Staphylococcus aureus Infections in Adults and Children: Executive Summary. Clin Infect Dis 2011;52:285-92, http://dx.doi.org/10.1093/cid/cir034.

[109] Duszyńska W. Strategies of empiric antibiotic therapy in severe sepsis. Anaesthesiol Intensive Ther 2012;44: 96-103.

[110] Garnacho-Montero J, Garcia-Garmendia JL, Barrero-Almodovar A, Jimenez-Jimenez FJ, Perez-Paredes C, Ortiz-Leyba C. Impact of adequate empirical antibiotic therapy on the outcome of patients admitted to the intensive care unit with sepsis. Crit Care Med 2003;31(December):2742-51

[111] Garnacho-Montero J, Aldabo-Pallas T, Garnacho-Montero C, et al. Timing of adequate antibiotic therapy is a greater determinant of outcome than are TNF and IL-10 polymorphisms in patients with sepsis. Crit Care Lond Engl 2006;10:R111, http://dx.doi.org/10.1186/cc4995.

[112] Kumar A, Roberts D, Wood KE, et al. Duration of hypotension before initiation of effective antimicrobial therapy is the critical determinant of survival in human septic shock. Crit Care Med 2006;34(June):1589-96, http://dx.doi.org/10.1097/01.CCM.0000217961.75225.E9.

[113] Ferrer R, Artigas A, Suarez D, et al. Effectiveness of treatments for severe sepsis: a prospective, multicenter, observational study. Am J Respir Crit Care Med 2009;180:861-6, http://dx.doi.org/10.1164/rccm.200812-1912OC.

[114] Castellanos-Ortega A, Suberviola B, Garcia-Astudillo LA, et al. Impact of the surviving sepsis campaign protocols on hospital length of stay and mortality in septic shock patients: results of a three-year follow-up quasiexperimental study. Crit Care Med 2010;38(April):1036-43, http://dx.doi.org/10.1097/CCM.0b013e3181d455b6.

[115] Barie PS, Hydo LJ, Shou J, Larone DH, Eachempati SR. Influence of Antibiotic Therapy on Mortality of Critical Surgical Illness Caused or Complicated by Infection. Surg Infect 2005;6:41-54, http://dx.doi.org/10.1089/sur.2005.6.41.

[116] MacArthur RD, Miller M, Albertson T, et al. Adequacy of Early Empiric Antibiotic Treatment and Survival in Severe Sepsis: Experience from the MONARCS Trial. Clin Infect Dis 2004;38:284-8, http://dx.doi.org/10.1086/379825.

[117] Kollef MH, Sherman G, Ward S, Fraser VJ. Inadequate antimicrobial treatment of infections: a risk factor for hospital mortality among critically ill patients. Chest J 1999;115:462-74, http://dx.doi.org/10.1378/chest.115.2.462.

[118] Ibrahim EH, Sherman G, Ward S, Fraser VJ, Kollef MH. THe influence of inadequate antimicrobial treatment of bloodstream infections on patient outcomes in the ICU setting. Chest J 2000;118:146-55, http://dx.doi.org/10.1378/chest.118.1.146.

[119] Hospital-acquired pneumonia in adults: diagnosis, assessment of severity, initial antimicrobial therapy, and preventive strategies. A consensus statement, American Thoracic Society, November 1995. Am J Respir Crit Care Med 1996;153:1711-25, http://dx.doi.org/10.1164/ajrccm.153.5.8630626.

[120] American Thoracic Society, Infectious Diseases Society of America. Guidelines for the management of adults with hospital-acquired, ventilator-associated, and healthcare-associated pneumonia. Am J Respir Crit Care Med 2005;171:388-416, http://dx.doi.org/10.1164/rccm.200405-644ST.

[121] Kollef MH, Morrow LE, Baughman RP, et al. Health care-associated pneumonia (HCAP): a critical appraisal to improve identification, management, and outcomes - proceedings of the HCAP summit. Clin Infect Dis 2008;46:S296-334, http://dx.doi.org/10.1086/526355.

[122] Raad I, Hanna H, Maki D. Intravascular catheter-related infections: advances in diagnosis, prevention, and management. Lancet Infect Dis 2007;7:645-57, http://dx.doi.org/10.1016/S1473-3099(07)70235-9.

[123] Beckers MMJ, Ruven HJT, Seldenrijk CA, Prins MH, Biesma DH. Risk of thrombosis and infections of central venous catheters and totally implanted access ports in 
patients treated for cancer. Thromb Res 2010;125:318-21, http://dx.doi.org/10.1016/j.thromres.2009.06.008.

[124] Corry J, Poon W, McPhee N, et al. Prospective study of percutaneous endoscopic gastrostomy tubes versus nasogastric tubes for enteral feeding in patients with head and neck cancer undergoing (chemo)radiation. Head Neck 2009;31:867-76, http://dx.doi.org/10.1002/hed.21044.

[125] Downey RJ, Friedlander P, Groeger J, et al. Critical care for the severely ill head and neck patient. Crit Care Med 1999;27(January):95-7.

[126] Hussain M, Kish JA, Crane L, et al. The role of infection in the morbidity and mortality of patients with head and neck cancer undergoing multimodality therapy. Cancer 1991;67:716-21

[127] Ryu CH, Roh J-L, Kim S-B, et al. Risk factors for non-cancer health events in patients with head and neck squamous cell carcinoma. Ann Oncol Off J Eur Soc Med Oncol 2013;24:1049-54, http://dx.doi.org/10.1093/annonc/mds540.

[128] Marik PE, Kaplan D. Aspiration pneumonia and dysphagia in the elderly. Chest 2003;124:328-36, http://dx.doi.org/10.1378/chest.124.1.328.

[129] Lalla RV, Latortue MC, Hong $\mathrm{CH}$, et al. A systematic review of oral fungal infections in patients receiving cancer therapy. Support Care Cancer 2010;18:985-92, http://dx.doi.org/10.1007/s00520-010-0892-z.

[130] Soga Y, Maeda Y, Ishimaru F, et al. Bacterial substitution of coagulase-negative staphylococci for streptococci on the oral mucosa after hematopoietic cell transplantation. Support Care Cancer Off J Multinatl Assoc Support Care Cancer 2011;19:995-1000, http://dx.doi.org/10.1007/s00520-010-0923-9.

[131] Napeñas JJ, Brennan MT, Coleman S, et al. Molecular methodology to assess the impact of cancer chemotherapy on the oral bacterial flora: a pilot study. Oral Surg Oral Med Oral Pathol Oral Radiol Endodontol 2010;109:554-60, http://dx.doi.org/10.1016/j.tripleo.2009.11.015.

[132] Van der Velden WJFM, Donnelly JP, Blijlevens NMA. Lymphocyte subsets, granulocyte-colony-stimulating factor responsiveness and post-stem cell transplantation infections: mucositis is the underestimated confounder? Cytotherapy 2012;14:381-3, http://dx.doi.org/10.3109/14653249.2011.650162.

[133] Costerton JW, Montanaro L, Arciola CR. Biofilm in implant infections: its production and regulation. Int $\mathrm{J}$ Artif Organs 2005;28:1062-8

[134] Bouza E, Burillo A, Muñoz P. Catheter-related infections: diagnosis and intravascular treatment. Clin Microbiol Infect 2002;8:265-74, http://dx.doi.org/10.1046/j.1469-0691.2002.00385.x.

[135] Maki DG, Kluger DM, Crnich CJ. The Risk of Bloodstream Infection in Adults With Different Intravascular Devices: A Systematic Review of 200 Published Prospective Studies. Mayo Clin Proc 2006;81:1159-71, http://dx.doi.org/10.4065/81.9.1159.

[136] Safdar N, Maki DG. Use of vancomycin-containing lock or flush solutions for prevention of bloodstream infection associated with central venous access devices: a meta-analysis of prospective, randomized trials. Clin Infect Dis 2006;43:474-84, http://dx.doi.org/10.1086/505976.

[137] Schiffer CA, Mangu PB, Wade JC, et al. Central venous catheter care for the patient with cancer: American society of clinical oncology clinical practice guideline. J Clin Oncol 2013;31:1357-70, http://dx.doi.org/10.1200/JCO.2012.45.5733.

[138] Mermel LA, Allon M, Bouza E, et al. Clinical practice guidelines for the diagnosis and management of intravascular catheter-related infection: 2009 update by the infectious diseases society of America. Clin Infect Dis 2009;49:1-45, http://dx.doi.org/10.1086/599376.

[139] Freifeld AG, Bow EJ, Sepkowitz KA, et al. Executive summary: clinical practice guideline for the use of antimicrobial agents in neutropenic patients with cancer: 2010 update by the infectious diseases society of America. Clin Infect Dis 2011;52:427-31, http://dx.doi.org/10.1093/cid/ciq147.
[140] Panghal M, Kaushal V, Kadayan S, Yadav J. Incidence and risk factors for infection in oral cancer patients undergoing different treatments protocols. BMC Oral Health 2012;12:22, http://dx.doi.org/10.1186/1472-6831-12-22.

[141] Luzzaro F, Viganò EF, Fossati D, et al. Prevalence and drug susceptibility of pathogens causing bloodstream infections in northern Italy: a two-year study in 16 hospitals. Eur J Clin Microbiol Infect Dis Off Publ Eur Soc Clin Microbiol 2002;21:849-55, http://dx.doi.org/10.1007/s10096-002-0837-7.

[142] Kanafani ZA, Dakdouki GK, El-Chammas KI, Eid S, Araj GF, Kanj SS. Bloodstream infections in febrile neutropenic patients at a tertiary care center in Lebanon: a view of the past decade. Int J Infect Dis 2007;11:450-3, http://dx.doi.org/10.1016/j.ijid.2006.12.008.

[143] Eachempati SR, Hydo LJ, Shou J, Barie PS. Does deescalation of antibiotic therapy for ventilator-associated pneumonia affect the likelihood of recurrent pneumonia or mortality in critically ill surgical patients? J Trauma 2009;66:1343-8, http://dx.doi.org/10.1097/TA.0b013e31819dca4e.

[144] Tang BM, Eslick GD, Craig JC, McLean AS. Accuracy of procalcitonin for sepsis diagnosis in critically ill patients: systematic review and meta-analysis. Lancet Infect Dis 2007;7:210-7, http://dx.doi.org/10.1016/S1473-3099(07)70052-X.

[145] Heyland DK, Johnson AP, Reynolds SC, Muscedere J. Procalcitonin for reduced antibiotic exposure in the critical care setting: a systematic review and an economic evaluation. Crit Care Med 2011;39(July):1792-9, http://dx.doi.org/10.1097/CCM.0b013e31821201a5.

[146] Jensen JU, Hein L, Lundgren B, et al. Procalcitonin-guided interventions against infections to increase early appropriate antibiotics and improve survival in the intensive care unit: a randomized trial. Crit Care Med 2011;39:2048-58, http://dx.doi.org/10.1097/CCM.0b013e31821e8791.

[147] Dellinger RP, Carlet JM, Masur H, et al. Surviving sepsis campaign guidelines for management of severe sepsis and septic shock. Crit Care Med 2004;32:858-73.

[148] Dellinger RP, Levy MM, Carlet JM, et al. Surviving sepsis campaign: international guidelines for management of severe sepsis and septic shock: 2008. Crit Care Med 2008;36:296-327, http://dx.doi.org/10.1097/01.CCM.0000298158.12101.41.

[149] Rivers E. The outcome of patients presenting to the emergency department with severe sepsis or septic shock. Crit Care 2006;10:154, http://dx.doi.org/10.1186/cc4973.

[150] Ganzer H, Touger-Decker R, Parrott J, Murphy B, Epstein J, Huhmann M. Symptom burden in head and neck cancer: impact upon oral energy and protein intake. Support Care Cancer 2013;21:495-503, http://dx.doi.org/10.1007/s00520-012-1542-4.

[151] Merlano M, Vitale V, Rosso R, et al. Treatment of advanced squamous-cell carcinoma of the head and neck with alternating chemotherapy and radiotherapy. N Engl J Med 1992;327:1115-21, http://dx.doi.org/10.1056/NEJM199210153271602.

[152] Adelstein DJ, Lavertu P, Saxton JP, et al. Mature results of a phase III randomized trial comparing concurrent chemoradiotherapy with radiation therapy alone in patients with Stage III and IV squamous cell carcinoma of the head and neck. Cancer 2000;88:876-83, 10.1002/(SICI)10970142(20000215)88:4<876::AID-CNCR19>3.0.CO;2-Y.

[153] Forastiere AA, Goepfert H, Maor M, et al. Concurrent chemotherapy and radiotherapy for organ preservation in advanced laryngeal cancer. N Engl J Med 2003;349:2091-8, http://dx.doi.org/10.1056/NEJMoa031317.

[154] Huguenin P, Beer KT, Allal A, et al. Concomitant cisplatin significantly improves locoregional control in advanced head and neck cancers treated with hyperfractionated radiotherapy. J Clin Oncol 2004;22:4665-73, http://dx.doi.org/10.1200/JCO.2004.12.193.

[155] Bonner JA, Harari PM, Giralt J, et al. Radiotherapy plus cetuximab for squamous-cell carcinoma of the head and neck. 
N Engl J Med 2006;354:567-78, http://dx.doi.org/10.1056/ NEJMoa053422.

[156] Rischin D, Peters LJ, O’Sullivan B, et al. Tirapazamine, cisplatin, and radiation versus cisplatin and radiation for advanced squamous cell carcinoma of the head and neck (TROG 02.02, HeadSTART): a Phase III Trial of the Trans-Tasman Radiation Oncology Group. J Clin Oncol 2010;28:2989-95, http://dx.doi.org/10.1200/JCO.2009.27.4449.

[157] Silver HJ, Dietrich MS, Murphy BA. Changes in body mass, energy balance, physical function, and inflammatory state in patients with locally advanced head and neck cancer treated with concurrent chemoradiation after low-dose induction chemotherapy. Head Neck 2007;29:893-900, http://dx.doi.org/10.1002/hed.20607.

[158] Flowers CR, Seidenfeld J, Bow EJ, et al. Antimicrobial prophylaxis and outpatient management of fever and neutropenia in adults treated for malignancy: American society of clinical oncology clinical practice guideline. J Clin Oncol 2013;31:794-810, http://dx.doi.org/10.1200/JCO.2012.45.8661.

[159] Fox AC, Robertson CM, Belt B, et al. Cancer causes increased mortality and is associated with altered apoptosis in murine sepsis. Crit Care Med 2010;38:886-93, http://dx.doi.org/10.1097/CCM.0b013e3181c8fdb1.

[160] Eilers RE, Gandhi M, Patel JD, et al. Dermatologic infections in cancer patients treated with epidermal growth factor receptor inhibitor therapy. J Natl Cancer Inst 2010;102:47-53, http://dx.doi.org/10.1093/jnci/djp439.

[161] Costa SF, Miceli MH, Anaissie EJ. Mucosa or skin as source of coagulase-negative staphylococcal bacteraemia? Lancet Infect Dis 2004;4:278-86, http://dx.doi.org/10.1016/S1473-3099(04)01003-5.

[162] Reddy BS, MacFie J, Gatt M, Macfarlane-Smith L, Bitzopoulou K, Snelling AM. Commensal bacteria do translocate across the intestinal barrier in surgical patients. Clin Nutr 2007;26:208-15, http://dx.doi.org/10.1016/j.clnu.2006.10.006.

[163] Paraskevas S, Huizinga JD, Loos BG. A systematic review and meta-analyses on C-reactive protein in relation to periodontitis. J Clin Periodontol 2008;35:277-90, http://dx.doi.org/10.1111/j.1600-051X.2007.01173.x.

[164] Linden GJ, Lyons A, Scannapieco FA. Periodontal systemic associations: review of the evidence. J Clin Periodontol 2013;40(Suppl. 14):S8-19, http://dx.doi.org/10.1111/jcpe. 12064.

[165] Russi EG, Bensadoun R-J, Merlano MC, et al. Bio-radiation dermatitis: the need of a new grading: in regard to Bernier et al: Ann Oncol 2011; 22(10): 2191-2200. Ann Oncol Off J Eur Soc Med Oncol 2013;24:2463-5, http://dx.doi.org/10.1093/annonc/mdt281.

[166] Merlano MC, Monteverde M, Colantonio I, et al. Impact of age on acute toxicity induced by bio- or chemo-radiotherapy in patients with head and neck cancer. Oral Oncol 2012;48:1051-7, http://dx.doi.org/10.1016/j.oraloncology.2012.05.001.

[167] Forner L, Larsen T, Kilian M, Holmstrup P. Incidence of bacteremia after chewing, tooth brushing and scaling in individuals with periodontal inflammation. J Clin Periodontol 2006;33:401-7, http://dx.doi.org/10.1111/j.1600-051X.2006.00924.x.

[168] Vincent J-L, Opal SM, Marshall JC, Tracey KJ. Sepsis definitions: time for change. Lancet 2013;2/381:774-5, http://dx.doi.org/10.1016/S0140-6736(12)61815-7.

[169] Vincent J-L, Moreno R, Takala J, et al. The SOFA (sepsisrelated organ failure assessment) score to describe organ dysfunction/failure. Intensive Care Med 1996;22:707-10, http://dx.doi.org/10.1007/BF01709751.

[170] ARDS Definition Task Force, Ranieri VM, Rubenfeld GD, et al. Acute respiratory distress syndrome: the Berlin Definition. J Am Med Assoc 2012;307:2526-33, http://dx.doi.org/10.1001/jama.2012.5669.

[171] Briel M, Meade M, Mercat A, et al. Higher vs lower positive end-expiratory pressure in patients with acute lung injury and acute respiratory distress syndrome: systematic review and meta-analysis. J Am Med Assoc 2010;303:865-73, http://dx.doi.org/10.1001/jama.2010.218.
[172] Levi M, Toh CH, Thachil J, Watson HG. Guidelines for the diagnosis and management of disseminated intravascular coagulation. British Committee for Standards in Haematology. Br J Haematol 2009;145:24-33, http://dx.doi.org/10.1111/j.1365-2141.2009.07600.x.

[173] Van den Berghe G, Wouters PJ, Bouillon R, et al. Outcome benefit of intensive insulin therapy in the critically ill: insulin dose versus glycemic control. Crit Care Med 2003;31:359-66, http://dx.doi.org/10.1097/01.CCM.0000045568.12881.10.

[174] Van den Berghe G, Wouters P, Weekers F, et al. Intensive insulin therapy in critically ill patients. N Engl J Med 2001;345:1359-67, http://dx.doi.org/10.1056/NEJMoa011300.

[175] NICE-SUGAR Study Investigators, Finfer S, Chittock DR, et al. Intensive versus conventional glucose control in critically ill patients. N Engl J Med 2009;360:1283-97, http://dx.doi.org/10.1056/NEJMoa0810625.

[176] Preiser J-C, Devos P, Ruiz-Santana S, et al. A prospective randomised multi-centre controlled trial on tight glucose control by intensive insulin therapy in adult intensive care units: the glucontrol study. Intensive Care Med 2009;35:1738-48, http://dx.doi.org/10.1007/s00134-009-1585-2.

[177] Arabi YM, Dabbagh OC, Tamim HM, et al. Intensive versus conventional insulin therapy: a randomized controlled trial in medical and surgical critically ill patients. Crit Care Med 2008;36:3190-7, http://dx.doi.org/10.1097/CCM.0b013e31818f21aa.

[178] Heidegger CP, Berger MM, Graf S, et al. Optimisation of energy provision with supplemental parenteral nutrition in critically ill patients: a randomised controlled clinical trial. Lancet 2013;381:385-93, http://dx.doi.org/10.1016/S0140-6736(12)61351-8.

[179] Bensadoun R-J, Patton LL, Lalla RV, Epstein JB. Oropharyngeal candidiasis in head and neck cancer patients treated with radiation: update 2011. Support Care Cancer 2011;19:737-44, http://dx.doi.org/10.1007/s00520-011-1154-4.

[180] Martin MV. The use of fluconazole and itraconazole in the treatment of Candida albicans infections: a review. J Antimicrob Chemother 1999;44:429-37, http://dx.doi.org/10.1093/jac/44.4.429.

[181] Ullmann AJ, Akova M, Herbrecht R, et al. ESCMID guideline for the diagnosis and management of Candida diseases 2012: adults with haematological malignancies and after haematopoietic stem cell transplantation (HCT). Clin Microbiol Infect 2012;18:53-67, http://dx.doi.org/10.1111/1469-0691.12041.

[182] Rajan S. Skin and soft-tissue infections: classifying and treating a spectrum. Cleve Clin J Med 2012;79:57-66, http://dx.doi.org/10.3949/ccjm.79a.11044.

[183] Mu YP, Liu RL, Wang LQ, et al. Moxifloxacin monotherapy for treatment of complicated intra-abdominal infections: a meta-analysis of randomised controlled trials. Int J Clin Pract 2012;66:210-7, http://dx.doi.org/10.1111/j.1742-1241.2011.02839.x.

[184] Chen C-W, Chu C-M, Ma C-J, Shan Y-S, Yeh Y-S, Wang J-Y. Prospective, randomized, study of ampicillin-sulbactam versus moxifloxacin monotherapy for the treatment of community-acquired complicated intra-abdominal infections. Surg Infect 2013;14:389-96, http://dx.doi.org/10.1089/sur.2012.017.

[185] Sartelli M. Antimicrobial management of intra-abdominal infections: literature's guidelines. World J Gastroenterol 2012;18:865, http://dx.doi.org/10.3748/wjg.v18.i9.865.

[186] Gould IM, Cauda R, Esposito S, Gudiol F, Mazzei T, Garau J. Management of serious meticillin-resistant Staphylococcus aureus infections: what are the limits? Int J Antimicrob Agents 2011;37:202-9, http://dx.doi.org/10.1016/j.ijantimicag.2010.10.030.

[187] Garnacho-Montero J, Sa-Borges M, Sole-Violan J, et al. Optimal management therapy for Pseudomonas aeruginosa ventilator-associated pneumonia: An observational, multicenter study comparing monotherapy with combination antibiotic therapy. Crit Care Med 2007;35(August):1888-95, http://dx.doi.org/10.1097/01.CCM.0000275389.31974.22. 
[188] Micek ST, Welch EC, Khan J, et al. Empiric combination antibiotic therapy is associated with improved outcome against sepsis due to gram-negative bacteria: a retrospective analysis. Antimicrob Agents Chemother 2010;54:1742-8, http://dx.doi.org/10.1128/AAC.01365-09.

[189] Klastersky J. Management of fever in neutropenic patients with different risks of complications. Clin Infect Dis 2004;39:S32-7, http://dx.doi.org/10.1086/383050.

[190] Al-Hasan MN, Wilson JW, Lahr BD, et al. $\beta$-Lactam and fluoroquinolone combination antibiotic therapy for bacteremia caused by Gram-negative bacilli. Antimicrob Agents Chemother 2009;53:1386-94, http://dx.doi.org/10.1128/AAC.01231-08.

[191] Kumar A, Zarychanski R, Light B, et al. Early combination antibiotic therapy yields improved survival compared with monotherapy in septic shock: a propensity-matched analysis. Crit Care Med 2010;38(September):1773-85, http://dx.doi.org/10.1097/CCM.0b013e3181eb3ccd.

[192] Kumar A, Safdar N, Kethireddy S, Chateau D. A survival benefit of combination antibiotic therapy for serious infections associated with sepsis and septic shock is contingent only on the risk of death: a metaanalytic/meta-regression study. Crit Care Med 2010;38:1651-64, http://dx.doi.org/10.1097/CCM.0b013e3181e96b91.

[193] Pitout JD, Laupland KB. Extended-spectrum $\beta$ lactamase-producing Enterobacteriaceae: an emerging public-health concern. Lancet Infect Dis 2008;8:159-66, http://dx.doi.org/10.1016/S1473-3099(08)70041-0.

\section{Biographies}

Russi, Elvio G., MD, (corresponding author) earned his M.D. degree at the University of Messina. He completed residency programs in Radiation Oncology, in Medical Oncology, and in Radiodiagnosis. He is currently Head of the Radiation Oncology department at Teaching Hospital "A.O. S. Croce e Carle" in Cuneo (Italy). Dr. Russi headed the "Head and neck study group" of Italian Association of Radiation Oncologist (AIRO) between 2012 and 2013. He was a board member for AIRO (Italian Association of Radiation Oncologist) between 2010 and 2012. He has authored or co-authored over 80 original articles, book chapters with a predominant emphasis on Head and neck cancer treatment. "Author H index": 13 (Scopus 2014).

Merlano, Marco C., MD, earned his M.D. degree at the University of Genoa. He is currently Chair of Oncological Department at Teaching Hospital "A.O. S. Croce e Carle" in Cuneo (Italy). Dr. Merlano has authored or co-authored over 135 original articles, book chapters with a predominant emphasis on Head and neck cancer treatment. "Author $\mathrm{H}$ index": 20 (Scopus 2014).

Licitra, Lisa, MD, is Chief of Head and neck cancer unitIstituto Nazionale dei Tumori Milano (Italy). She specialized in Medical Oncology at the University of Parma. Dr. Licitra was Chair of Head and neck cancer group of EORTC (European Organization For Research And Treatment Of Cancer)-member of PDQ (Physician's Data Query) of the National Cancer Institute USA. She is honorary member of European Society For Therapeutic Radiology And Oncology
(ESTRO). Member of the editorial board - Cancer Treatment Reviews (2007-2009). She has authored or co-authored over 135 original articles, book chapters with a predominant emphasis on Head and neck cancer treatment. "Author $\mathrm{H}$ index": 27 (Scopus 2014).

Cascio, Antonio, PhD, is Professor of Infectious disease, University of Messina, Italy. Dr. Cascio has authored or coauthored over 150 original articles, book chapter. "Author h-index": 25 (Scopus 2014).

Bernier, Jacques, MD, is Head of the Radio-Oncology Division at the Swiss Genolier Medical Network, in Geneva, Switzerland. He is Professor at Faculty of Medicine, University of Geneva Switzerland. Dr. Bernier has been heavily involved with clinical research, including studies of novel technologies in radiotherapy, and biochemical and biological modifiers of tumor response to ionizing radiation. A Faculty member at the European School of Oncology, he is also the Past- Chairman of the Head and Neck Group of the EORTC (European Organization for Research and Treatment of Cancer, Brussels, Belgium), Chairman of the European InterGroup of Head and Neck Oncology, President of the Foundation for the Advancement of Radiation Oncology (FARO Foundation) in Geneva, and a Member of the Scientific Committee of the Umberto Veronesi Foundation in Milan, Italy. Bernier's research focuses on the development of novel treatments combining local and systemic treatments. $\mathrm{He}$ is author or co- author of more than 185 scientific contributions (original articles, review articles, editorials, book chapters) in peer-reviewed publications. He is the Editor of a Textbook to be published by Humana Press/Springer in early 2010 ("Multi-Disciplinary Treatments in Head-andNeck cancer Patients"). "Author H- index": 41 (Scopus 2014).

Vermorken, Jan Baptist, MD, is Emeritus professor Universiteit Antwerpen, Department of Medical Oncology, Antwerpen, Belgium. He received his $\mathrm{PhD}$ in Medical Sciences in 1986 from the Vrije Universiteit in Amsterdam. From May 1997 until October 1, 2009, he was Professor of Oncology at the University of Antwerp (UA), and head of the Department of Medical Oncology at the University Hospital Antwerp (UZA), in Edegem, Belgium. After his retirement he remains connected to both University (emeritus Professor) and University Hospital. His main fields of interest are gynecologic oncology, and head and neck oncology. He is member of the European Society of Gynecology (ESGO) and was ESGO council member from 1989-2000. Since 1985 he is member of the EORTC Head and Neck Cancer Group, served as chairman of its Subcommittee for Chemotherapy (1985-1991), was secretary of the group from 1995 to 2006 and chaired the group from 2006 to 2009 . He chaired the National Representatives Committee from 1991 to 1996 and the Educational Committee from 1996 to 2002 of ESMO. During that whole period he was member of the ESMO Executive Committee. He was Editor-in-Chief of Annals 
of Oncology, the official journal of the European Society for Medical Oncology and the Japanese Society of Medical Oncology (2009-2014). Dr. Vermorken has authored or co-authored over 380 original articles book chapters. "Author H index": 60(Scopus 2014).

Murphy, Barbara A., MD, graduated from the Wake Forest University School of Medicin. Fellowship in medical oncology at Memorial Sloan-Kettering Cancer Center; internal medicine Residency at Greenwich Hospital (Yale University affiliated). She is Professor of Medicine (Hematology/Oncology), Director of Head \& Neck Oncology, Program Director of Pain \& Symptom Management Program in Vanderbilt University, Nashville, USA. Dr. Murphy has authored or co-authored over 110 original articles, book chapters, with a predominant emphasis on supportive care and on improving survival and quality of life in patients with head and neck treated with chemo-radiation therapy. "Author h-index": 36 (Scopus 2014).

Ranieri, Vito Marco, MD, is Professor and Chair, Department of Surgical Sciences, at University of Turin, Italy.
He has authored or co-authored over 220 original articles, book chapters, with a predominant emphasis on anaesthesiology, mechanical ventilation for respiratory pathology, and epidemiology and outcome of acute respiratory failure in intensive care unit patients. "Author H index": 52(Scopus 2014).

Dellinger, R. Phillip, MD is Professor of Medicine at Cooper Medical School of Rowan University and Director of Critical Care at Cooper University Hospital, Camden, New Jersey. He received his medical degree from the Medical University of South Carolina and did his residency and fellowship training at Wilford Hall USAF Medical Center, San Antonio, TX. Dr. Dellinger has authored or co-authored over 250 original articles, book chapters, abstracts and films with a predominant emphasis on sepsis. He is co-editor of the second, third, and fourth edition of Critical Care Medicine textbook (Mosby), and associate editor for Critical Care Medicine journal. He is a past president of the Society of Critical Care Medicine (SCCM). "Author H index”: 39(Scopus 2014). 